\title{
Asymptomatic Carotid Artery Stenosis: Past, Present and Future
}

\section{How to Improve Patient Selection?}

\author{
A. Rijbroek $^{a}$ W. Wisselink ${ }^{b} \quad$ E.M. Vriens ${ }^{c} \quad$ F. Barkhof ${ }^{d} \quad$ A.A. Lammertsma ${ }^{e}$ \\ J.A. Rauwerdab \\ ${ }^{a}$ Department of General Surgery, Kennemer Gasthuis, Haarlem, Departments of ${ }^{b}$ General Surgery,

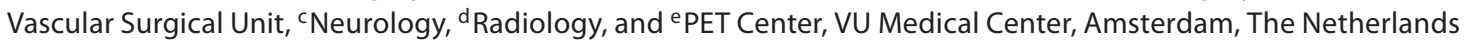

\section{Key Words}

Asymptomatic carotid artery stenosis $\cdot$ Natural history $\cdot$

Risk of stroke $\cdot$ Carotid endarterectomy $\cdot$ Cerebral

hemodynamics $\cdot$ Cerebral metabolism · Plaque

morphology

\begin{abstract}
Background: The role of carotid endarterectomy (CEA) for asymptomatic carotid artery stenosis (aCAS) remains a matter of debate. It seems that not only the degree of stenosis, but also other factors have to be taken in account to improve patient selection and increase the benefit of CEA for aCAS. Methods and Results: The literature pertaining aCAS was reviewed in order to describe the natural history, risk of stroke and benefit of CEA for patients with aCAS in regard to several factors. Conclusion: The benefit of CEA for aCAS is low. Current factors influencing the indication for CEA are severity of stenosis, age, contralateral disease, stenosis progression to $>80 \%$, gender, concomitant operations and life expectancy. To improve patient selection investigations will concentrate on plaque characteristics and instability and cerebral hemodynamics and metabolism.
\end{abstract}

Copyright $\odot 2006$ S. Karger AG, Basel (c) 2006 S. Karger AG, Basel

0014-3022/06/0563-0139\$23.50/0

Fax +41613061234 E-Mail karger@karger.ch www.karger.com www.karger.com/ene

\section{Introduction}

Since the publication of the North American Symptomatic Carotid Endarterectomy Trial (NASCET) and the European Carotid Surgery Trial (ECST) results in 1991, the benefits and indications of CEA in symptomatic patients are clearly defined $[1,2]$. The results of these studies have led to an increasing number of CEAs.

Because of the impressive results of CEA for symptomatic disease, studies on the effect of CEA for asymptomatic CAS as primary prevention were conducted.

The most two striking studies were the Asymptomatic Carotid Atherosclerosis Stenosis Study (ACAS) with 1,662 patients, which was published in 1995 and the Asymptomatic Carotid Surgery Trial (ACST) with 3,120 patients, which was published in 2004 [3, 4]. These studies showed that CEA was beneficial for asymptomatic patients if a CAS $>60 \%$ was present. In addition, it was shown that the perioperative neurological complication rate was less than $3 \%$. As a result, the number of CEAs for asymptomatic CAS was rising in several countries, although the benefits were not as convincing as those shown in the NASCET and ECST. Although a relative risk reduction of more than $50 \%$ in stroke for patients who underwent CEA seems substantial, a meta-analysis of CEA for asymptomatic CAS, performed in 1998 before

A. Rijbroek

Department of General Surgery, Kennemer Gasthuis

PO Box 417

NL-2000 AK Haarlem (The Netherlands)

Tel. +31 23545 3656, Fax +31 23535 3649, E-Mail rijbroek@kg.nl 
the results of ACST, only showed a $2 \%$ absolute risk reduction in stroke [5]. It was concluded that the benefit of CEA was small, because the annual stroke rate in medically treated patients with an asymptomatic CAS $>60 \%$ is $2-6 \%$. In addition, especially in the ACAS trial, both surgeons and patients had to fulfill certain selection criteria to be included. In the ACAS, surgeons had to have proven competence and expertise performing more then 12 CEAs annually and having a complication rate of less than $3 \%$, in the ACST trial less than 6\% $[4,6]$. Some exclusion criteria in ACAS for patients were diabetes and age older than 79 years. It was calculated that number needed to treat (NNT) was 17 patients for ACAS and 19 patients for ACST. Compared to symptomatic carotid stenosis the NNT is between 2 and 12 patients [7].

Finally, there is evidence that $20-45 \%$ of strokes in patients with CAS are not attributed to the stenosis, but have small vessel disease or cardioembolic causes [8].

The finding of an asymptomatic CAS constitutes a dilemma for the surgeon. At present, the natural history of an asymptomatic CAS in the individual patient is unknown. Most likely a subgroup exists that will benefit from an operation, whilst other asymptomatic patients are better treated with medication. Clearly, the risk of perioperative neurological morbidity and mortality must be weighed against the risk of an ischemic event after medical treatment. In addition, the effectiveness of carotid surgery can also be improved by focusing on a reduction in complication rate, taking into account both surgical technique and type of anesthesia.

The purpose of the present review was to provide an overview of the various aspects of asymptomatic CAS that are important for appropriate patient selection. In addition, the potential role of some risk factors in identifying patients with increased risk of stroke who would benefit for surgery is discussed and potential developments in patients selection are described.

\section{Prevalence of Asymptomatic CAS}

A stenosis of the carotid artery greater than $50 \%$ is considered to be significant carotid artery disease. As asymptomatic CAS patients have no complaints, they can only be detected through screening or by chance. Screening tests are performed for several reasons, although the clinical consequences of these tests can be discussed. Screening tests are for example performed in case of preoperative evaluation of coronary artery bypass grafting (CABG), cervical bruits by physical examination or eval- uation of ipsilateral symptomatic carotid artery disease with by chance detection of asymptomatic contralateral CAS. The prevalence rate of asymptomatic CAS $>50 \%$ is estimated to lie between 2 and $8 \%$ and that of asymptomatic CAS $>80 \%$ between 1 and $2 \%$ [9]. There is a strong dependency on age. Obviously, prevalence rates of asymptomatic CAS are higher in selected patients (table 1) [10-28]. An association between several (vascular) risk factors and asymptomatic CAS has been demonstrated. Prevalence rates for asymptomatic CAS $>50 \%$ as high as $10-30 \%$ have been found in patients with cervical bruits, coronary artery disease, hypercholesterolemia, diabetes, peripheral atherosclerotic occlusive disease (PAOD) and in smokers (table 1). Stratification, however, is only useful if it affects patients' management. Prevalence of asymptomatic CAS therefore is closely related to risk of stroke and benefit of CEA.

\section{Severity of Stenosis and Risk of Stroke}

Knowledge about the natural history of asymptomatic CAS has not only been derived from screening and follow-up studies, but also from trials in which the effect of CEA was compared with medical treatment and from studies in patients with CEA for ipsilateral symptomatic stenosis and asymptomatic contralateral disease.

Risk of any ipsilateral neurological deficit increases with the severity of the asymptomatic CAS. Published annual risk of ipsilateral neurological deficits for asymptomatic CAS $<50 \%$, between 50 and $80 \%$ and $>80 \%$ are $0-3.8 \%, 2-5 \%$ and $1.7-18 \%$, respectively (table 2 ) [3, 12 , $18,29-44]$. The majority of these neurological deficits seems transient neurological attacks (TIAs) or amaurosis fugax, but risk of ipsilateral stroke or permanent neurological deficit must not be underestimated and can affect up to half of these patients. Asymptomatic CAS $<50 \%$, between 50 and $80 \%$ and $>80 \%$, carry a risk of stroke of less than $1 \%, 0.8-2.4 \%$ and $1-5 \%$ per year, respectively (table 2).

Like prevalence rates, these data depend on the study population examined. There is agreement that screening of asymptomatic CAS in the general population using duplex ultrasound is not justified, because of the low prevalence rates and the very low annual stroke rates. Based on the results of the ACAS, it was estimated that 1,700 persons must need to be screened to prevent 1 ipsilateral stroke from an asymptomatic CAS $\geq 80 \%$ [9]. In patients with vascular risk factors like cervical bruits, PAOD or advanced age, the prevalence of asymptomatic CAS 
Table 1. Reported prevalence rates of aCAS in several different study population

\begin{tabular}{|c|c|c|c|c|c|c|c|c|c|}
\hline Reference & Year & $\begin{array}{l}\text { Screening } \\
\text { population }\end{array}$ & Patients & $\begin{array}{l}\text { Mean } \\
\text { age } \\
\text { years }\end{array}$ & $\begin{array}{l}\text { Male/ } \\
\text { female }\end{array}$ & $\begin{array}{l}\text { Exami- } \\
\text { nation }\end{array}$ & \multicolumn{2}{|c|}{$\begin{array}{l}\text { Prevalence aCAS } \\
\%\end{array}$} & Risk factors aCAS \\
\hline $\begin{array}{l}\text { Hennerici } \\
\text { et al. [10] }\end{array}$ & 1981 & $\begin{array}{l}\text { cardiovascular } \\
\text { disease }\end{array}$ & 2,009 & 58 & $\begin{array}{c}1,647 \mathrm{M} \\
362 \mathrm{~F}\end{array}$ & doppler & $\geq 50$ & 9.1 & vascular disease \\
\hline $\begin{array}{l}\text { Ramsey } \\
\text { et al. [11] }\end{array}$ & 1987 & general, age $>50$ & 102 & 62 & $\begin{array}{l}45 \mathrm{M} \\
57 \mathrm{~F}\end{array}$ & doppler & $\geq 40$ & 5.9 & heart disease \\
\hline $\begin{array}{l}\text { Hennerici } \\
\text { et al. [12] }\end{array}$ & 1987 & $\begin{array}{l}\text { vascular risk } \\
\text { factors }\end{array}$ & 3,225 & 62 & n.a. & doppler & $\begin{array}{c}50-80 \\
80-99 \\
\text { occlusion }\end{array}$ & $\begin{array}{l}6.2 \\
1.3 \\
1.7\end{array}$ & \\
\hline $\begin{array}{l}\text { Josse } \\
\text { et al. [13] }\end{array}$ & 1987 & general & 526 & $45-84$ & $\begin{array}{l}222 \mathrm{M} \\
304 \mathrm{~F}\end{array}$ & duplex & $\geq 50$ & 2.1 & age $>75$ years \\
\hline $\begin{array}{l}\text { Colgan } \\
\text { et al. [14] }\end{array}$ & 1988 & general & 348 & 61 & $\begin{array}{l}139 \mathrm{M} \\
209 \mathrm{~F}\end{array}$ & duplex & $\begin{array}{l}50-79 \\
\geq 80\end{array}$ & $\begin{array}{l}3 \\
1\end{array}$ & age $\geq 70$ years, hypertension \\
\hline $\begin{array}{l}\text { Faggioli } \\
\text { et al. [15] }\end{array}$ & 1990 & CABG & 539 & 63 & $\begin{array}{l}376 \mathrm{M} \\
163 \mathrm{~F}\end{array}$ & duplex & $\geq 75$ & 8.7 & age $>60$ years \\
\hline $\begin{array}{l}\text { Ahn } \\
\text { et al. [16] }\end{array}$ & 1991 & PAOD & 78 & 70 & $\begin{array}{l}54 \mathrm{M} \\
24 \mathrm{~F}\end{array}$ & duplex & $\begin{array}{l}50-75 \\
\geq 75\end{array}$ & $\begin{array}{l}9 \\
4\end{array}$ & $\begin{array}{l}\text { age } \geq 68 \text { years, } \\
\text { hypertension }\end{array}$ \\
\hline $\begin{array}{l}\text { Klop } \\
\text { et al. [17] }\end{array}$ & 1991 & PAOD & 416 & 67 & $\begin{array}{l}282 \mathrm{M} \\
134 \mathrm{~F}\end{array}$ & duplex & $\begin{array}{l}50-75 \\
75-99 \\
\text { occlusion }\end{array}$ & $\begin{array}{r}10.1 \\
7.7 \\
7.2\end{array}$ & \\
\hline $\begin{array}{l}\text { Ellis } \\
\text { et al. [18] }\end{array}$ & 1992 & vascular disease & 1,196 & 68 & $\begin{array}{l}826 \mathrm{M} \\
370 \mathrm{~F}\end{array}$ & $\begin{array}{l}\text { doppler } \\
\text { duplex }\end{array}$ & $\begin{array}{l}50-79 \\
\geq 80\end{array}$ & $\begin{array}{l}11 \\
2.8\end{array}$ & \\
\hline $\begin{array}{l}\text { O'Leary } \\
\text { et al. [19] }\end{array}$ & 1992 & age $>65$ & 5,116 & n.a. & $\begin{array}{l}2,210 \mathrm{M} \\
2,906 \mathrm{~F}\end{array}$ & duplex & $\begin{array}{l}50-75 \\
75-99 \\
\text { occlusion }\end{array}$ & 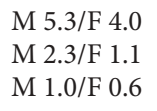 & $\begin{array}{l}\text { men, hypertension, smoking, } \\
\text { coronary artery disease, } \\
\text { wall thickness }\end{array}$ \\
\hline $\begin{array}{l}\text { Fine-Edelstein } \\
\text { et al. [20] }\end{array}$ & 1994 & $\begin{array}{l}\text { general } \\
\text { population }\end{array}$ & 1,116 & $66-93$ & $\begin{array}{l}441 \mathrm{M} \\
675 \mathrm{~F}\end{array}$ & duplex & $\geq 50$ & M 9/F 7 & $\begin{array}{l}\text { age, smoking, hypertension, } \\
\text { cholesterol }\end{array}$ \\
\hline $\begin{array}{l}\text { Gentile } \\
\text { et al. [21] }\end{array}$ & 1995 & $\begin{array}{l}\text { infrainguinal } \\
\text { bypass surgery }\end{array}$ & 252 & 67 & $\begin{array}{l}117 \mathrm{M} \\
108 \mathrm{~F}\end{array}$ & duplex & $\begin{array}{l}\text { 60-99 } \\
\text { occlusion }\end{array}$ & $\begin{array}{r}12 \\
3\end{array}$ & \\
\hline $\begin{array}{l}\text { Marek } \\
\text { et al. [22] }\end{array}$ & 1996 & claudication & 188 & 64 & $\begin{array}{c}142 \mathrm{M} \\
46 \mathrm{~F}\end{array}$ & duplex & $\begin{array}{c}50-80 \\
80-99 \\
\text { occlusion }\end{array}$ & $\begin{array}{l}20 \\
1.6 \\
2.7\end{array}$ & $\begin{array}{l}\text { age }>65 \text { years, cervical bruit, } \\
\mathrm{ABI}<0.7\end{array}$ \\
\hline $\begin{array}{l}\text { House } \\
\text { et al. [23] }\end{array}$ & 1999 & PAOD & 486 & 71 & $\begin{array}{l}302 \mathrm{M} \\
184 \mathrm{~F}\end{array}$ & duplex & $\begin{array}{c}50-70 \\
70-99 \\
\text { occlusion }\end{array}$ & $\begin{array}{r}17 \\
13 \\
5\end{array}$ & $\begin{array}{l}\text { aneurysm, smoking and } \\
\text { creatinine (males) }\end{array}$ \\
\hline $\begin{array}{l}\text { Ascher } \\
\text { et al. [24] }\end{array}$ & 1999 & $\begin{array}{l}\text { referred to } \\
\text { vascular surgeon }\end{array}$ & 307 & $>65$ & $\begin{array}{l}157 \mathrm{M} \\
150 \mathrm{~F}\end{array}$ & duplex & $\geq 70$ & 21 & \\
\hline $\begin{array}{l}\text { Simons } \\
\text { et al. [25] }\end{array}$ & 1999 & PAOD & 162 & 61 & $\begin{array}{c}104 \mathrm{M} \\
58 \mathrm{~F}\end{array}$ & duplex & $\geq 50$ & 14 & $\begin{array}{l}\text { age } \geq 67 \text { years, weight } \\
\leq 68 \mathrm{~kg}, \mathrm{DBP} \leq 75 \mathrm{~mm} \mathrm{Hg}\end{array}$ \\
\hline $\begin{array}{l}\text { Cheng } \\
\text { et al. [26] }\end{array}$ & 1999 & PAOD & 186 & 71 & $\begin{array}{l}121 \mathrm{M} \\
65 \mathrm{~F}\end{array}$ & duplex & $\geq 70$ & 25 & age, smoking, cervical bruit \\
\hline $\begin{array}{l}\text { Qureshi } \\
\text { et al. [27] }\end{array}$ & 2001 & general & 1,331 & 66 & $\begin{array}{l}439 \mathrm{M} \\
892 \mathrm{~F}\end{array}$ & duplex & $\geq 60$ & 18 & $\begin{array}{l}\text { age }>65 \text { years, smoking, } \\
\text { coronary artery disease, } \\
\text { hypercholesterolemia }\end{array}$ \\
\hline $\begin{array}{l}\text { Cina } \\
\text { et al. [28] }\end{array}$ & 2002 & PAOD & 620 & 72 & $\begin{array}{l}376 \mathrm{M} \\
244 \mathrm{~F}\end{array}$ & duplex & $\begin{array}{l}50-80 \\
\geq 80\end{array}$ & $\begin{array}{l}30 \\
2.5\end{array}$ & $\begin{array}{l}\text { age }>70 \text { years, diabetes, } \\
\mathrm{ABI}<0.8\end{array}$ \\
\hline
\end{tabular}

n.a. = Not available or not mentioned; PAOD = peripheral arterial occlusive disease $\mathrm{ABI}=$ ankle brachial index; $\mathrm{DBP}=$ diastolic blood pressure 
Table 2. Risk of annual (ipsilateral) neurological deficits, stroke and risk factors in selected patients with asymptomatic CAS according to severity of stenosis

\begin{tabular}{|c|c|c|c|c|c|c|c|c|c|c|c|c|}
\hline Reference & Year & $\begin{array}{l}\text { Screening } \\
\text { population }\end{array}$ & $\begin{array}{l}\mathrm{Pa}- \\
\text { tients }\end{array}$ & $\begin{array}{l}\text { Age } \\
\text { (mean) } \\
\text { years }\end{array}$ & $\begin{array}{l}\text { Male/ } \\
\text { female }\end{array}$ & $\begin{array}{l}\text { Exami- } \\
\text { nation }\end{array}$ & $\begin{array}{l}\text { Prevalence } \\
\%\end{array}$ & aCAS & $\begin{array}{l}\text { Median } \\
\text { follow- } \\
\text { up, } m\end{array}$ & $\begin{array}{l}\text { Risk annual } \\
\text { ipsilateral neu- } \\
\text { rological event }\end{array}$ & $\begin{array}{l}\text { Risk annual } \\
\text { ipsilateral } \\
\text { stroke }\end{array}$ & $\begin{array}{l}\text { Risk factors any } \\
\text { neurological } \\
\text { event }\end{array}$ \\
\hline $\begin{array}{l}\text { Chambers } \\
\text { et al. [29] }\end{array}$ & 1986 & cervical bruits & 500 & 63 & $\begin{array}{l}212 \mathrm{M} \\
288 \mathrm{~F}\end{array}$ & $\begin{array}{l}\text { doppler } \\
\text { angiography }\end{array}$ & $\begin{array}{l}<75 \\
\geq 75\end{array}$ & $\begin{array}{l}77.4 \\
22.6\end{array}$ & 23 & $\begin{array}{l}3.6 \% \\
1 \text { st year } \\
18 \%\end{array}$ & $\begin{array}{l}1.5 \% \\
5 \%\end{array}$ & $\begin{array}{l}\text { aCAS }>75 \% \text {, } \\
\text { progression, heart } \\
\text { disease, men }\end{array}$ \\
\hline $\begin{array}{l}\text { Autret } \\
{[30]}\end{array}$ & 1987 & $\begin{array}{l}\text { cardiovascular } \\
\text { disease }\end{array}$ & 242 & 67 & $\begin{array}{c}149 \mathrm{M} \\
93 \mathrm{~F}\end{array}$ & duplex & $\begin{array}{l}<50 \\
50-75 \\
\geq 75\end{array}$ & $\begin{array}{l}53 \\
31 \\
16\end{array}$ & 29 & $\begin{array}{l}0.23 \% \\
2.48 \% \\
1.71 \%\end{array}$ & $\begin{array}{l}0 \% \\
0.8 \% \\
1.7 \%\end{array}$ & $\begin{array}{l}\text { aCAS }>50 \% \text {, age, } \\
\text { cholesterol, systolic } \\
\text { blood pressure }\end{array}$ \\
\hline $\begin{array}{l}\text { Hennerici } \\
\text { et al. [12] }\end{array}$ & 1987 & $\begin{array}{l}\text { cardiovascular } \\
\text { disease }\end{array}$ & 284 & 62 & $\begin{array}{l}201 \mathrm{M} \\
138 \mathrm{~F}\end{array}$ & duplex & $\begin{array}{l}50-80 \\
\geq 80\end{array}$ & $\begin{array}{l}70.1 \\
29.9\end{array}$ & 29 & $3.5 \% *$ & $0.97 \% *$ & $\begin{array}{l}\text { occlusion, } \\
\text { progression }\end{array}$ \\
\hline $\begin{array}{l}\text { O’Holleran } \\
\text { et al. [31] }\end{array}$ & 1987 & $\begin{array}{l}\text { cardiovascular } \\
\text { disease }\end{array}$ & 293 & n.a. & n.a. & duplex & $\begin{array}{l}<75 \\
\geq 75\end{array}$ & $\begin{array}{l}59 \\
41\end{array}$ & 46 & $\begin{array}{l}2.5 \% \\
12.5 \%\end{array}$ & $\begin{array}{l}0.6 \% \\
3.2 \%\end{array}$ & $\begin{array}{l}\text { aCAS }>75 \% \text {, soft } \\
\text { plaques }\end{array}$ \\
\hline $\begin{array}{l}\text { Norris } \\
\text { et al. [32] }\end{array}$ & 1991 & cervical bruits & 696 & 64 & $\begin{array}{l}327 \mathrm{M} \\
369 \mathrm{~F}\end{array}$ & doppler & $\begin{array}{l}<75 \\
\geq 75\end{array}$ & $\begin{array}{l}74.6 \\
25.4\end{array}$ & 41 & $\begin{array}{l}2.0 \% \mathrm{i}+\mathrm{c} \\
10.5 \% \mathrm{i}+\mathrm{c}\end{array}$ & $\begin{array}{l}1.3 \% \mathrm{i}+\mathrm{c} \\
2.5 \% \mathrm{i} \\
3.3 \% \mathrm{i}+\mathrm{c}\end{array}$ & $\begin{array}{l}\text { heart disease, } \\
\text { aCAS }>75 \%\end{array}$ \\
\hline $\begin{array}{l}\text { Ellis } \\
\text { et al. [18] }\end{array}$ & 1992 & $\begin{array}{l}\text { vascular } \\
\text { disease }\end{array}$ & 1,196 & 68 & $\begin{array}{l}826 \mathrm{M} \\
370 \mathrm{~F}\end{array}$ & $\begin{array}{l}\text { doppler } \\
\text { duplex }\end{array}$ & $\begin{array}{l}<50 \\
50-79 \\
\geq 80\end{array}$ & $\begin{array}{c}86.2 \\
11 \\
2.8 \\
\end{array}$ & 20 & $\begin{array}{l}2.5 \% \\
4.2 \% \\
7.5 \% \\
\end{array}$ & $\begin{array}{l}1.2 \% \\
2.2 \% \\
0 \% \\
\end{array}$ & aCAS $>80 \%$ \\
\hline $\begin{array}{l}\text { Mess } \\
\text { et al. [33] }\end{array}$ & 1992 & n.a. & 446 & n.a. & n.a. & n.a. & $\geq 80$ & & 61 & n.a. & $1.7 \%$ & \\
\hline $\begin{array}{l}\text { Shanik } \\
\text { et al. [34] }\end{array}$ & 1992 & $\begin{array}{l}\text { vascular } \\
\text { disease }\end{array}$ & 188 & 69 & $\begin{array}{l}114 \mathrm{M} \\
74 \mathrm{~F}\end{array}$ & duplex & $\begin{array}{l}<50 \\
50-79 \\
\geq 80\end{array}$ & $\begin{array}{l}51 \\
18 \\
31 \\
\end{array}$ & 48 & $\begin{array}{l}0.5 \% \\
15 \% \\
3.6 \% \\
\end{array}$ & $\begin{array}{l}0.5 \% \\
1 \% \\
1.8 \% \\
\end{array}$ & $\begin{array}{l}\text { progression, } \\
\text { aCAS }>80 \%\end{array}$ \\
\hline $\begin{array}{l}\text { Bock } \\
\text { et al. [35] }\end{array}$ & 1993 & $\begin{array}{l}\text { cervical bruits } \\
\text { vascular } \\
\text { disease }\end{array}$ & 242 & 68 & $\begin{array}{c}191 \mathrm{M} \\
51 \mathrm{~F}\end{array}$ & duplex & $\begin{array}{l}<50 \\
50-79 \\
80-99\end{array}$ & $\begin{array}{r}73 \\
19 \\
3\end{array}$ & 27 & $\begin{array}{l}3.8 \% \\
3.1 \% \\
5.1 \%\end{array}$ & $\begin{array}{l}\text { n.a. } \\
\text { n.a. } \\
\text { n.a. }\end{array}$ & $\begin{array}{l}\text { progression, } \\
\text { echolucent } \\
\text { plaques }\end{array}$ \\
\hline $\begin{array}{l}\text { Hobson } \\
\text { et al. [36] }\end{array}$ & 1993 & $\mathrm{aCAS} \geq 50 \%$ & 233 & 65 & $233 \mathrm{M}$ & $\begin{array}{l}\text { duplex } \\
\text { angiography }\end{array}$ & $\geq 50$ & & 48 & $5.1 \%$ & $2.4 \%$ & \\
\hline ACAS3 & 1995 & $\mathrm{aCAS} \geq 60 \%$ & 834 & 67 & $\begin{array}{l}550 \mathrm{M} \\
284 \mathrm{~F}\end{array}$ & $\begin{array}{l}\text { angiography } \\
\text { doppler }\end{array}$ & $\geq 60$ & & 31 & $3.8 \%$ & $2.2 \%$ & \\
\hline ECST37 & 1995 & $\begin{array}{l}\text { contralateral } \\
\text { sCAS }\end{array}$ & 2,295 & 62 & $\begin{array}{c}1,629 \mathrm{M} \\
666 \mathrm{~F}\end{array}$ & angiography & $\begin{array}{l}<70 \\
\geq 70 \\
\text { occlusion }\end{array}$ & $\begin{array}{r}92.1 \\
5.5 \\
2.4\end{array}$ & 44 & n.a. & $\begin{array}{l}0.65 \% \\
1.9 \% \\
1.2 \%\end{array}$ & \\
\hline $\begin{array}{l}\text { Naylor } \\
\text { et al. [38] }\end{array}$ & 1995 & $\begin{array}{l}\text { contralateral } \\
\text { CEA }\end{array}$ & 219 & n.a. & n.a. & $\begin{array}{l}\text { angiography } \\
\text { duplex }\end{array}$ & $\begin{array}{l}<70 \\
\geq 70 \\
\text { occlusion }\end{array}$ & $\begin{array}{r}85 \\
4 \\
11\end{array}$ & 48 & $2 \%^{*}$ & $1 \%^{*}$ & \\
\hline $\begin{array}{l}\text { Tong } \\
\text { et al. [39] }\end{array}$ & 1996 & cervical bruits & 336 & 65 & $\begin{array}{l}149 \mathrm{M} \\
187 \mathrm{~F}\end{array}$ & $\begin{array}{l}\text { duplex } \\
\text { angiography }\end{array}$ & $\begin{array}{l}<60 \\
\geq 60 \\
\text { occlusion }\end{array}$ & $\begin{array}{r}81.7 \\
15.3 \\
3.0\end{array}$ & 58 & $\begin{array}{l}0.6 \% \\
3.9 \% \\
4.2 \%\end{array}$ & $\begin{array}{l}0.1 \% \\
0.85 \% \\
1 \%\end{array}$ & aCAS $>80 \%$ \\
\hline $\begin{array}{l}\text { Mackey } \\
\text { et al. [40] }\end{array}$ & 1997 & cervical bruits & 715 & 65 & $\begin{array}{l}283 \mathrm{M} \\
432 \mathrm{~F}\end{array}$ & duplex & $\begin{array}{l}<50 \\
\geq 50 \\
80-99\end{array}$ & $\begin{array}{l}50 \\
50 \\
15.8\end{array}$ & 42 & $\begin{array}{l}2.7 \mathrm{i}+\mathrm{c} \\
6.8 \% \mathrm{i}+\mathrm{c}, \\
4.2 \% \mathrm{i}(7.5 \% \mathrm{i})\end{array}$ & $\begin{array}{l}1.3 \mathrm{i}+\mathrm{c} \\
2.2 \mathrm{i}+\mathrm{c}, 1.4 \% \mathrm{i} \\
(2.8 \% \mathrm{i})\end{array}$ & $\mathrm{i}$ \\
\hline $\begin{array}{l}\text { Irvine } \\
\text { et al. [41] }\end{array}$ & 1998 & aCAS $\geq 40 \%$ & 487 & 69 & $\begin{array}{l}292 \mathrm{M} \\
195 \mathrm{~F}\end{array}$ & duplex & $\geq 40$ & & 41 & n.a. & $\begin{array}{l}1 \% \\
(2.74 \% \mathrm{i}+\mathrm{c})\end{array}$ & bilateral disease \\
\hline $\begin{array}{l}\text { Longstreth } \\
\text { et al. [42] }\end{array}$ & 1998 & age $>65$ years & 5,441 & 73 & $\begin{array}{l}2,231 \mathrm{M} \\
3,210 \mathrm{~F}\end{array}$ & duplex & $\geq 70$ & 0.5 & 60 & $1.8 \%$ & $1 \%$ & \\
\hline $\begin{array}{l}\text { Nadareishvili } \\
\text { et al. [43] }\end{array}$ & 2002 & cervical bruits & 106 & 64 & $\begin{array}{l}62 \mathrm{M} \\
44 \mathrm{~F}\end{array}$ & duplex & $\begin{array}{l}<50 \\
50-99\end{array}$ & $\begin{array}{l}48 \text { pat. } \\
58 \text { pat. }\end{array}$ & 120 & $\begin{array}{l}\text { n.a. } \\
\text { n.a. }\end{array}$ & $\begin{array}{l}5.7 \% \\
(10 \text { years }) \\
9.3 \% \\
(10 \text { years })\end{array}$ & \\
\hline ACST4 & 2004 & $\mathrm{aCAS} \geq 60 \%$ & 1,560 & 68 & $\begin{array}{c}1,023 \mathrm{M} \\
537 \mathrm{~F}\end{array}$ & duplex & $\geq 60$ & & 40 & n.a. & $1.4 \%$ & Age $<75$ years \\
\hline $\begin{array}{l}\text { Nicolaides } \\
\text { et al. [44] }\end{array}$ & 2005 & $\mathrm{aCAS} \geq 50 \%$ & 1,115 & n.a. & n.a. & duplex & $\geq 50$ & & 37 & $1.4 \%$ & $0.6 \%$ & $\begin{array}{l}\text { aCAS } \geq 90 \% \text {, } \\
\text { creatinine } \uparrow, \\
\text { contralateral TIA }\end{array}$ \\
\hline
\end{tabular}

n.a. $=$ Not available or not mentioned. ${ }^{*}$ Risk of event in all patients not specified to the degree of carotid artery stenosis; $\mathrm{i}=\mathrm{ipsilateral;} \mathrm{c}=$ contralateral. A difference between ipsilateral and contralateral has not been made in all studies. 
Table 3. Percent sensitivity and specificity of duplex, MRA and CTA for carotid artery stenosis according to the literature

\begin{tabular}{|c|c|c|c|c|c|c|}
\hline & \multicolumn{2}{|c|}{ Stenosis $\geq 50 \%$} & \multicolumn{2}{|c|}{ Stenosis $\geq 70 \%$} & \multicolumn{2}{|c|}{ Occlusion } \\
\hline & sensitivity & specificity & sensitivity & specificity & sensitivity & specificity \\
\hline Duplex & $87-95$ & $83-96$ & $65-97$ & $75-97$ & $80-100$ & $90-100$ \\
\hline MRA & 92 & 74 & $94-100$ & $85-100$ & 100 & 100 \\
\hline CTA & $85-90$ & $82-91$ & $67-100$ & $84-100$ & $69-100$ & $87-100$ \\
\hline
\end{tabular}

$\geq 50 \%$ and/or $>80 \%$ raises to between 10 and $59 \%$, but the annual risk of ipsilateral stroke in this groups remains low $(1-4 \%)$ and therefore the benefit of screening to prevent stroke is questionable.

To improve the efficacy of screening tests, decision trees were developed, including different strategies and variables, such as prevalence and natural history of asymptomatic CAS, annual risk of stroke and death, accuracy of diagnostic tests, risk of surgery and angiography. It was estimated that the prevalence rate of asymptomatic CAS $>50 \%$ in the population to be screened should be between 20 and $50 \%$ to be effective $[45,46]$. At present, this prevalence rate is not even achieved in selected populations and therefore screening for asymptomatic CAS seems not effective.

Not only does the severity of the stenosis affect the decision to operate for asymptomatic CAS, but also the risk of stroke in case of an occlusion. For asymptomatic patients, it was estimated that about $20 \%$ of all occurring carotid occlusions were associated with ischemic events and that the annual stroke rate after an occlusion was $2-6 \%$ [47-50]. To prevent these occlusions and because of the elevated risk of stroke for asymptomatic CAS $>80 \%$, the (worldwide) tendency is to operate on asymptomatic CAS $>80 \%[51]$.

\section{Diagnostic Imaging of CAS}

The degree of carotid stenosis in ACAS, ECST and NASCET was determined with angiography. The main disadvantages of angiography, however, are its invasiveness and the reported $0.16-3 \%$ morbidity and mortality rate. The most widely used method for determining the degree of stenosis with angiography is according to the NASCET method, which relates the point of greatest stenosis to the normal distal ICA. In the ECST study, the greatest stenosis was related to the estimated diameter of the normal carotid bulb, which provides a more severe stenosis compared with the NASCET method.

Asymptomatic Carotid Artery Stenosis
Nowadays, several noninvasive diagnostic imaging techniques are available to evaluate the degree of a CAS (table 3).

Sensitivity and specificity are between 62 and 100\%, but are depending on technique and diagnostic criteria [52].

Duplex ultrasound provides an excellent noninvasive, inexpensive instrument to assess the degree of a stenosis and was used in the ACST. With duplex both the peak systolic velocity (PSV) and end-diastolic velocity (EDV) are determined in the common and internal carotid arteries. In case of bilateral carotid artery disease the measurement of absolute velocities can overestimate the degree of the stenosis and ratios of velocities are recommended. The main difficulties with duplex ultrasound are the interlaboratory variations in stenosis evaluation and interpretation criteria. Therefore, recommending CEA only based on duplex ultrasound remains a matter of debate. MRA and CTA are promising noninvasive techniques, although not available everywhere. A proposed strategy is to combine imaging techniques. Duplex ultrasound is used as the primary screening tool for CAS and if CEA is considered, MRA or CTA is performed. In case of discrepancies angiography is recommended [52, 53].

\section{Progression of the Severity of the Stenosis}

The risk of progression of an asymptomatic CAS increases with time and varies from 4 to $29 \%$ per year, depending on the definitions of stenosis progression and studied population (table 4) $[28,35,40,51,54-60]$. Several studies have tried to describe the natural history of asymptomatic CAS, to define risk factors or predictors for stenosis progression by multiple linear regression analysis, and to find a relation between stenosis progression and neurological symptoms.

The sometimes conflicting results of all these studies are difficult to compare, because the target population, 
Table 4. Reported incidence of progression rate of asymptomatic CAS and risk of neurological events

\begin{tabular}{|c|c|c|c|c|c|c|c|c|c|c|c|c|}
\hline & \multirow[t]{2}{*}{ Year } & \multirow{2}{*}{$\begin{array}{l}\mathrm{Pa}- \\
\text { tients }\end{array}$} & \multirow{2}{*}{$\begin{array}{l}\text { Age } \\
\text { (mean) } \\
\text { years }\end{array}$} & \multirow{2}{*}{ Sex } & \multicolumn{2}{|c|}{ Initial stenosis } & \multirow{2}{*}{$\begin{array}{l}\text { Mean } \\
\text { follow- } \\
\text { up } \\
\text { months }\end{array}$} & \multirow{2}{*}{\multicolumn{2}{|c|}{ Progression rate }} & \multicolumn{2}{|c|}{ Progression vs. no-progression group } & \multirow{2}{*}{$\begin{array}{l}\text { Risk factors } \\
\text { progression }\end{array}$} \\
\hline & & & & & $\%$ & $\%$ & & & & $\begin{array}{l}\text { ipsilateral neurolo- } \\
\text { gical event rate }\end{array}$ & $\begin{array}{l}\text { ipsilateral } \\
\text { stroke rate }\end{array}$ & \\
\hline $\begin{array}{l}\text { Roederer } \\
\text { et al. [60] }\end{array}$ & 1984 & 162 & 64 & $\begin{array}{c}110 \mathrm{M} \\
52 \mathrm{~F}\end{array}$ & $\begin{array}{l}<50 \\
50-79 \\
80-99 \\
\text { occlusion }\end{array}$ & $\begin{array}{r}64 \\
29 \\
3 \\
4\end{array}$ & 15 & $\begin{array}{l}\text { overall } \\
\text { aCAS } \geq 50 \%\end{array}$ & $\begin{array}{l}20 \% / \text { year } \\
8 \% / \text { year }\end{array}$ & $\begin{array}{l}\text { to } \geq 80 \text { vs. } \\
<80 \% \text {; } \\
33 \% \text { vs. } 0.4 \%\end{array}$ & $\begin{array}{l}\text { to } \geq 80 \text { vs. } \\
<80 \% \text {; } \\
12.5 \% \text { vs. } 0 \%\end{array}$ & $\begin{array}{l}\text { smoking, } \\
\text { diabetes, } \\
\text { age }<65\end{array}$ \\
\hline $\begin{array}{l}\text { Hatsumaki } \\
\text { et al. [55] }\end{array}$ & 1990 & 200 & 65 & $\begin{array}{c}138 \mathrm{M} \\
62 \mathrm{~F}\end{array}$ & $\begin{array}{l}<50 \\
50-79 \\
80-99\end{array}$ & $\begin{array}{r}63 \\
33 \\
4\end{array}$ & 54 & $\begin{array}{l}\text { aCAS } \geq 50 \% \\
\text { aCAS } \geq 80 \%\end{array}$ & $\begin{array}{l}3.9 \% \\
1.2 \%\end{array}$ & no difference & no differences & \\
\hline $\begin{array}{l}\text { Bock } \\
\text { et al. [35] }\end{array}$ & 1993 & 242 & 68 & $\begin{array}{c}191 \mathrm{M} \\
51 \mathrm{~F}\end{array}$ & $\begin{array}{l}<50 \\
50-79 \\
80-99\end{array}$ & $\begin{array}{r}61 \\
25 \\
5\end{array}$ & 27 & $\begin{array}{l}\text { overall } \\
\text { in follow-up }\end{array}$ & $14.8 \%$ & $11 \%$ vs. $1.7 \%$ & n.a. & \\
\hline $\begin{array}{l}\text { Johnson } \\
\text { et al. [55] }\end{array}$ & 1995 & 232 & 63 & $\begin{array}{c}136 \mathrm{M} \\
96 \mathrm{~F}\end{array}$ & $\begin{array}{l}<50 \\
50-79\end{array}$ & $\begin{array}{l}59.5 \\
43.5\end{array}$ & 84 & $\begin{array}{l}\text { to } 80-99 \% \\
\text { aCAS }<50 \% \\
\text { aCAS } 50-79 \%\end{array}$ & $\begin{array}{r}4 \% \text { in } 7 \text { years } \\
26 \% \text { in } 7 \text { years }\end{array}$ & n.a. & $\begin{array}{l}14.8 \% \text { vs. } 2.3 \% \\
\text { after } 7 \text { years }\end{array}$ & \\
\hline $\begin{array}{l}\text { Mackey } \\
\text { et al. [40] }\end{array}$ & 1997 & 715 & 65 & $\begin{array}{l}283 \mathrm{M} \\
432 \mathrm{~F}\end{array}$ & $\begin{array}{l}<50 \\
50-79 \\
80-99 \\
\text { occlusion }\end{array}$ & $\begin{array}{l}50 \\
29 \\
15.8 \\
5.2\end{array}$ & 42 & $\begin{array}{r}8.3 \% \\
16.4 \% \\
12.2 \%\end{array}$ & & $\begin{array}{l}\text { to } \geq 80 \% \text { vs. }<80 \% \\
19.2 \% \text { vs. } 2.9 \% \\
\text { to } \geq 50 \% \text { vs. }<50 \% \\
13 \% \text { vs. } 2.9 \%\end{array}$ & & \\
\hline $\begin{array}{l}\text { Rockman } \\
\text { et al. [51] }\end{array}$ & 1997 & 425 & 75 & $\begin{array}{l}219 \mathrm{M} \\
206 \mathrm{~F}\end{array}$ & $50-79$ & & 38 & $\begin{array}{r}4.9 \% \\
16.7 \% \\
26.5 \%\end{array}$ & $\begin{array}{l}1 \text { year } \\
3 \text { year } \\
5 \text { year }\end{array}$ & $\begin{array}{l}37.5 \% \text { vs. } 7.3 \% \\
\text { in follow-up }\end{array}$ & $\begin{array}{l}10.4 \% \text { vs. } 2.1 \% \\
\text { in follow-up }\end{array}$ & \\
\hline $\begin{array}{l}\text { Olin } \\
\text { et al. [59] }\end{array}$ & 1998 & 465 & 69 & $\begin{array}{l}255 \mathrm{M} \\
210 \mathrm{~F}\end{array}$ & $60-79$ & & 24 & $\begin{array}{r}5 \% \\
11 \% \\
20 \%\end{array}$ & $\begin{array}{l}1 \text { year } \\
2 \text { year } \\
3 \text { year }\end{array}$ & & $\begin{array}{l}5.6 \% \text { vs. } 0.76 \% \\
\text { in follow-up }\end{array}$ & \\
\hline $\begin{array}{l}\text { Mansour } \\
\text { et al. [57] }\end{array}$ & 1999 & 344 & 71 & $344 \mathrm{M}$ & $50-79$ & & 25 & overall & $\begin{array}{l}15.5 \% \text { in } \\
\text { follow-up }\end{array}$ & $\begin{array}{l}26 \% \text { vs } 12 \% \\
\text { in follow-up }\end{array}$ & $\begin{array}{l}10.2 \% \text { vs. } 2.5 \% \\
\text { in follow-up }\end{array}$ & $\begin{array}{l}\text { heart disease, } \\
\text { black race }\end{array}$ \\
\hline $\begin{array}{l}\text { Muluk } \\
\text { et al. [58] }\end{array}$ & 1999 & 1,004 & 66 & $\begin{array}{c}984 \mathrm{M} \\
20 \mathrm{~F}\end{array}$ & $\begin{array}{l}<50 \\
50-79 \\
\geq 80\end{array}$ & $\begin{array}{l}75 \\
14 \\
11\end{array}$ & 28 & overall & $9.3 \% /$ year & $\begin{array}{l}21.1 \%-11.9 \% \\
\text { in follow-up }\end{array}$ & & $\begin{array}{l}\text { ipsilateral } \\
\text { aCAS } \geq 50 \% \\
\text { ipsilateral } \\
\text { ECAS } \geq 50 \% \\
\text { contralateral } \\
\text { ICAS } \geq 50 \% \\
\text { systolic BP } \\
>160 \mathrm{~mm} \mathrm{Hg}\end{array}$ \\
\hline $\begin{array}{l}\text { Liapsis } \\
\text { et al. [56] }\end{array}$ & 2000 & 442 & 69 & $\begin{array}{l}320 \mathrm{M} \\
122 \mathrm{~F}\end{array}$ & $\begin{array}{l}<50 \\
\geq 50\end{array}$ & $\begin{array}{l}69 \\
31\end{array}$ & 44 & overall & $15 \% /$ year & $\begin{array}{l}20.7 \% \text { vs. } 6.1 \% \\
\text { in follow-up } \\
\text { (TIAs) }\end{array}$ & $\begin{array}{l}11.2 \% \text { vs. } 1.9 \% \\
\text { in follow-up }\end{array}$ & $\begin{array}{l}\text { coronary } \\
\text { artery disease, } \\
\text { echolucent } \\
\text { plaques }\end{array}$ \\
\hline $\begin{array}{l}\text { Cina } \\
\text { et al. [28] }\end{array}$ & 2002 & 417 & 73 & $\begin{array}{l}259 \mathrm{M} \\
158 \mathrm{~F}\end{array}$ & $\begin{array}{l}<50 \\
50-99\end{array}$ & $\begin{array}{l}72.4 \\
23.3\end{array}$ & $\begin{array}{l}6 \text { to } \\
9\end{array}$ & overall & $\begin{array}{l}16 \% \text { in } \\
\text { follow-up }\end{array}$ & & $\begin{array}{l}\text { no difference } \\
\text { (short } \\
\text { follow-up) }\end{array}$ & \\
\hline
\end{tabular}

n.a. $=$ Not available or not mentioned

initial stenosis and follow-up period differ in most studies and not always a difference was made between transient versus permanent neurological deficit.

Most studies show an increasing rate of ipsilateral neurological events with stenosis progression especially for stenosis progression greater than $80 \%$, although the an- nual incidence rate of stroke in the progression patients remains low $(<5 \%)$. Prophylactic CEA is only suggested after progression occurs to a more than $80 \%$ stenosis, as rapidly progressive carotid stenosis seems to increase the risk of stroke. The problem is that in probably half of the patients' progression will be detected after the onset of 
neurological symptoms and it is therefore not always a useful predictor of future neurological events. The ideal time interval between repeated duplex measurements to detect stenosis progression is unknown and has yet to be determined.

\section{Carotid Plaque Morphology}

Histological studies have shown that in symptomatic plaques, the amount of lipids is greater, rupture or ulceration, inflammation and thin fibrous capping more common. Plaque rupture can cause intraplaque hemorrhage and lumen thrombosis and eventually embolization [61].

By ultrasonographic evaluation, the degree of echogenicity of a carotid plaque can be assessed and expressed on a grey scale. A low grey scale suggests a lipid-rich plaque. Characterization of the carotid plaque is according to Gray-Weale (type 1-4) or to Geroulakos (type I to V) classification (type 1/I: uniformly echolucent plaques with or without a thin echogenic cap; type $2 /$ II: predominantly echolucent plaques with less than $50 \%$ echogenic areas; type 3/III predominantly echogenic plaques with less than 50\% echolucent areas; type 4/IV: uniformly echogenic plaques; type V: plaques that cannot be classified due to heavy calcification producing acoustic shadows) $[62,63]$.

Echolucent or hypoechoic plaques are characterized by low values of the grey scale median (GSM) and are associated with symptomatic lesions, suggesting plaque instability. Echorich or hyperechoic plaques have high values of GSM and are related to asymptomatic stenosis [6466]. In addition, a positive relation has been described between echolucent plaques and nonlacunar silent brain infarcts [67].

A prospective study confirmed the association between future risk of stroke and echolucency of carotid atherosclerotic plaques, but only in previously symptomatic patients and not in asymptomatic patients [68].

Variations in plaque echoicity distinguish homogeneous from heterogenous plaques, but conflicting data exist between variation in plaque echoicity and risk of stroke $[64,69,70]$. The disadvantage of ultrasonographic plaque morphology evaluation is its observer variability and visual analysis. Computer-aided methods are needed and already used for objective evaluation of plaque echoicity, but larger studies are necessary to investigate the risk of stroke and plaque echoicity [71].

TCD was in addition used to study plaque instability and embolization. A relation between the number of si- lent embolic signals and the risk of ipsilateral neurological symptoms has been described in both symptomatic and asymptomatic carotid stenosis [72-76]. Spiral CT of plaque calcification and histological analysis have demonstrated that symptomatic plaques are less calcified and more inflamed than asymptomatic plaques [77]. Also with specific MRI techniques, morphology of carotid plaques can be obtained. MRI characterization and identification of unstable vulnerable plaques (ruptured fibrous cap) correlates well with histological sections and is associated with recent ischemic events [78-80].

Although the prognostic implications are not completely clear, plaque characteristics might contribute to proper patient selection for CEA. This selection should not only be confined to symptomatic patients with stenosis $<70 \%$, but also to asymptomatic patients with all degrees of stenosis.

\section{Silent Cerebral Infarcts on the Asymptomatic Site}

It is conceivable that asymptomatic CAS patients with cerebral infarction on CT or MRI are prone to a stroke and that the stenosis has already resulted embolisms, with silent cerebral infarctions and/or nondetectable neurological symptoms.

A relation between number of cerebral infarctions and the severity of the symptoms was described in ACST. Although the ACST randomized asymptomatic patients for CEA or best medical treatment and investigated the stroke free survival, an analysis was performed for patients with contralateral symptoms. In this group of patients, the number of infarctions on CT decreased from $62,30,17$ to $10 \%$ for, respectively, contralateral stroke, TIAs, amaurosis fugax and asymptomatic patients, respectively. With MRI, the incidence of hemispheric infarctions decreased from $53 \%, 27$ to $14 \%$ for patients with prior contralateral stroke, TIAs or amaurosis fugax and no prior symptoms, respectively [81].

Hougaku et al. [82] demonstrated silent cerebral infarctions on MRI in $42 \%$ of 117 subjects with asymptomatic carotid lesions. Multivariate analysis revealed a significant correlation of silent infarcts with age, hypertension, plaque score, high-grade stenosis and/or ulcerated lesions. In contrast, Cao et al. [83] found no relation between degree of stenosis and silent cerebral infarctions on CT in asymptomatic patients with CAS $<60 \%$ and $>60 \%$. In fact, as patients with silent cerebral infarctions had a shorter 10-year survival and a poorer neurologic outcome, they proposed a less aggressive approach towards 
CEA in asymptomatic patients with silent cerebral infarctions. Brott et al. [84] also found no association between silent infarcts and the degree of stenosis in the ACAS study.

Although a relation between symptoms and number of cerebral infarctions seems clear, the benefit of CEA in asymptomatic patients for silent cerebral infarctions alone is not proven.

\section{Influence of Contralateral Carotid Artery Disease}

Studies on the natural history and/or surgical risks of an asymptomatic CAS in the presence of contralateral carotid artery disease are difficult to compare. A difference between symptomatic and asymptomatic ipsilateral CAS is not always made, and the number of patients is usually limited and several subgroups with contralateral disease can be distinguished, such as patients with a contralateral occlusion (symptomatic or asymptomatic), patients with a contralateral stenosis (symptomatic or asymptomatic), patients with different degrees of stenosis, and patients with no stenosis.

The stroke risk in unilateral asymptomatic CAS seems to be lower than in bilateral asymptomatic CAS. In a follow-up study (mean 41 months) of 487 asymptomatic patients, the risk of ipsi- and contralateral stroke was significantly increased in bilateral disease (relative risk 2.35). A stroke rate of $9.6 \%$ in patients with bilateral disease and a $>90 \%$ contralateral stenosis was seen after 1 year of follow-up [41].

An interesting observation was made in a post hoc analysis of the ACAS trial, where patients with asymptomatic CAS $>60 \%$ and contralateral occlusion were stratified to surgery or medical management. The 5 -year ipsilateral stroke rate in the medically treated patients with a contralateral occlusion had a remarkably better outcome, not only compared with surgery (3.5\% vs. $5.5 \%)$, but also with the medically treated patients without contralateral occlusion (11.7\%). It was hypothesized that the contralateral occlusion stimulates the development of collateral circulation. No difference was found in 5-year ipsilateral stroke in operated patients with and without a contralateral occlusion (5.5 vs. $5.0 \%$ ), suggesting that there was no increased surgical risk in asymptomatic patients with a contralateral occlusion [85]. In contrast, in ACST the status of the contralateral carotid artery showed no influence in 5 -year outcome, but the number of patients with contralateral occlusion in both studies was small. AbuRahma et al. [86] reported a 5-year ipsilateral stroke rate of $27 \%$ in conservative management of patients with asymptomatic CAS $>60 \%$ and a contralateral occlusion.

Goldstein et al. [87] studied risk factors in CEA for asymptomatic CAS in 463 patients and found an increased, but not significant, complication rate in patients with a higher degree of contralateral stenosis and/or occlusions compared with patients with no contralateral CAS (3.6-4.0\% vs. 1.4-1.6\%). Nicolaides et al. [44] found in the Asymptomatic Carotid Stenosis and Risk of Stroke Study Group (ACSRS) that severity of aCAS, history of contralateral TIA and elevated creatinine were independent risk factors. If all three were present, the annual stroke risk in patients with 90-99\% aCAS increased from 1 to $6.3 \%$.In CAS, with contralateral ICA occlusion there is a trend that the risk of CEA is slightly elevated, especially in the presence of a contralateral symptomatic ICA occlusion [88-90]. Other studies (including both asymptomatic and symptomatic patients) found similar results of perioperative, all stroke and survival rates in patients with and without contralateral ICA occlusion [91-94].

It appears that there is conflicting information about the role of the contralateral carotid artery in case of an ipsilateral asymptomatic CAS caused by the heterogeneity of the population. Management needs to be based on weighing several risk factors in the individual patient. It seems that the surgical risk in the presence of contralateral carotid disease is about twofold higher than in asymptomatic CAS without contralateral carotid disease and comparable to the surgical results obtained in symptomatic carotid artery disease.

\section{Gender}

In conservative treatment of asymptomatic CAS, gender seems to be no risk factor for stroke, but there are several reports indicating that women have a significantly higher risk of perioperative stroke in asymptomatic as well as symptomatic disease than men. ACAS found a complication rate of $3.6 \%$ for women, compared to $1.7 \%$ for men [3]. These results were confirmed by Goldstein et al. [87] who reported a complication rate of $5.3 \%$ for women versus $1.6 \%$ for men ( $\mathrm{p}=0.02)$ in CEA for asymptomatic disease. For symptomatic carotid artery disease similar findings were reported in the ECST $[88,95]$. Other studies, including asymptomatic and symptomatic patients, reported no differences in perioperative neurologic events in men and women $[96,97]$.

In contrast there are no reports of increased risk in men. Although the risk of perioperative stroke in women 
Table 5. Reported number of deaths, strokes, cardiac- and stroke-related mortality at follow-up

\begin{tabular}{|c|c|c|c|c|c|c|c|c|c|}
\hline \multirow{2}{*}{$\begin{array}{l}\text { Reference } \\
\text { Chambers et al. [29] }\end{array}$} & \multirow{2}{*}{$\begin{array}{c}\text { Year } \\
1986\end{array}$} & \multirow{2}{*}{$\begin{array}{c}\text { Patients } \\
500\end{array}$} & \multirow{2}{*}{$\begin{array}{l}\begin{array}{l}\text { Follow- } \\
\text { up } \\
\text { months }\end{array} \\
23\end{array}$} & \multirow{2}{*}{$\begin{array}{l}\text { Deaths } \\
45\end{array}$} & \multirow{2}{*}{$\begin{array}{l}\begin{array}{l}\text { Ipsi- } \\
\text { lateral } \\
\text { strokes }\end{array} \\
12\end{array}$} & \multicolumn{2}{|c|}{$\begin{array}{l}\text { Stroke-related } \\
\text { mortality and \% } \\
\text { in follow-up }\end{array}$} & \multicolumn{2}{|c|}{$\begin{array}{l}\text { Cardiovascular- } \\
\text { related mortality } \\
\text { and } \% \text { in follow-up }\end{array}$} \\
\hline & & & & & & 3 & $13 \%$ & 27 & $60 \%$ \\
\hline Hennerici et al. [12] & 1987 & 339 & 33 & 82 & 17 & 10 & $12 \%$ & 35 & $43 \%$ \\
\hline Autret [30] & 1987 & 242 & 29 & 56 & 10 & 2 & $3.6 \%$ & na & \\
\hline Hatsukami et al. [55] & 1990 & 200 & 54 & 39 & 6 & 2 & $5 \%$ & 17 & $44 \%$ \\
\hline Norris et al. [32] & 1991 & 696 & 41 & 95 & 29 & 5 & $5.2 \%$ & 59 & $62 \%$ \\
\hline Ellis et al. [18] & 1992 & 1,198 & 60 & 155 & 27 & 11 & $7.1 \%$ & na & \\
\hline Hobson et al. [36] & 1993 & 233 & 48 & 77 & 29 & 4 & $5.2 \%$ & 47 & $61 \%$ \\
\hline ACAS3 & 1995 & 834 & 31 & 89 & 52 & 9 & $10.1 \%$ & 48 & $54 \%$ \\
\hline Naylor et al. [38] & 1995 & 219 & 48 & 44 & 10 & 2 & $4.5 \%$ & 22 & $50 \%$ \\
\hline Tong et al. [39] & 1996 & 336 & 58 & 41 & 9 & 2 & $4.9 \%$ & 23 & $56 \%$ \\
\hline Irvine et al. [41] & 1998 & 487 & 41 & 156 & 45 & 23 & $14.8 \%$ & 79 & $51 \%$ \\
\hline Mansour et al. [57] & 1999 & 344 & 25 & 75 & 14 & 11 & $14.7 \%$ & 36 & $48 \%$ \\
\hline Liapsis et al. [56] & 2000 & 442 & 44 & 33 & 16 & 2 & $6.1 \%$ & 25 & $76 \%$ \\
\hline Nadareishvilli et al. [43] & 2002 & 106 & 120 & 17 & 11 & 2 & $11.8 \%$ & 10 & $59 \%$ \\
\hline ACST [4] & 2004 & 1,560 & 40 & 248 & 62 & 44 & $2.8 \%$ & 127 & $51 \%$ \\
\hline Nicolaides et al. [44] & 2005 & 1,115 & 37 & 163 & 46 & 8 & $17.5 \%$ & 105 & $64 \%$ \\
\hline
\end{tabular}

is low, there seem to be a tendency of a similar to twofold higher risk in women. This effect of gender on outcome in CEA especially in asymptomatic disease raised the question whether CEA is beneficial for women with asymptomatic CAS, but so far no consensus has been reached.

\section{Age}

The prevalence of CAS is dependent on age. Below the age of 60 years the prevalence of a more than $50 \%$ stenosis is estimated to be $0.5 \%$, but it increases to $10 \%$ above the age of 80 years. Studies concerning the early operative results and late outcome of patients $>75$ years show different results, but a distinction between symptomatic and asymptomatic disease is not always made. In most prospective clinical trials like NASCET and ACAS, age $>80$ years was an exclusion criteria. In ACST benefit for patients $>75$ years was small, with an absolute 5 -year risk reduction of $3.3 \%(\mathrm{NNT}=30)$ [4]. In a review on risk factors for asymptomatic disease, an increased postoperative stroke or death rate in those aged 75 years or older ( 7.8 vs. $1.8 \%$ in those younger than 75 years; $p=0.01$ ) was described in a study of 463 CEAs [87]. Perler et al. [98] described a perioperative stroke and death rate of $2.6 \%$ in 1,036 patients $>80$ years, but no difference between asymptomatic and symptomatic patients was made. Ker- diles et al. [99] found that $90.9 \%$ of 252 patients $>75$ years were free from neurological deficiency after CEA for symptomatic and asymptomatic disease after 5 years compared with $92.4 \%$ of 660 patients $<75$ years. The actual 5 -year survival was $73 \%$ in the older and $85 \%$ in the younger patients.

In $182 \mathrm{CEAs}$ ( $55 \%$ for asymptomatic disease and mean age 83 years), O'Hara et al. [100] reported a postoperative neurological event rate of $2.7 \%$ in octogenarians and an estimated 5-year stroke-free rate of $85 \%$, although the 5year survival rate was just $45 \%$.

It appears that age in itself is not an absolute contraindication for carotid artery surgery [90]. The elderly patients should be selected according to the same criteria, but it is important to take into account life expectancy and other risk factors.

\section{Life Expectancy}

Clinical studies have shown that asymptomatic CAS is an associated risk factor for cardiovascular disease and death and that it seems to be a stronger predictor of death than self-reported cardiovascular disease or diabetes [101]. In all studies shown in table 2, the annual risk of death seems higher than the risk of a neurological event in patients with all degrees of asymptomatic CAS, especially with regard to the risk of stroke. Follow-up studies have 
shown that the number of cardiac-related deaths exceeds the number of strokes and the stroke-related death is low compared to the cardiac-related death (table 5), the latter being accountable for about $30-50 \%$ of all mortalities [11, $17,28,29,31,36-38,40,42,58-60]$. To improve life expectancy, it is therefore emphasized that prevention of stroke in asymptomatic CAS should also be accompanied by prevention and analysis of coronary artery disease.

\section{Concomitant Operations}

There is no evidence that patients with asymptomatic CAS $>70 \%$, who have to undergo noncarotid surgery benefit from a prophylactic CEA, except probably in case of coronary artery bypass grafting (CABG) [102]. A recent review by Naylor et al. [103] analyzed several factors influencing the risk of stroke after CABG. An increased risk was found in neurologically symptomatic patients compared with asymptomatic patients ( 8.5 vs. $2.2 \%)$ and in patients with severe carotid artery stenosis. It seems, however, that about $60 \%$ of perioperative stroke cannot be attributed to carotid artery disease. There is just one study investigating asymptomatic patients only [104]. The risk of an ipsilateral stroke was $3.6 \%$ for an $80-99 \%$ stenosis compared with $0.4 \%$ in a normal or $<80 \%$ CAS. Because the prevalence of $80-99 \%$ stenosis in asymptomatic patients undergoing CABG is only $5 \%$, the benefit of prophylactic CEA in asymptomatic patients before CABG is low. A staged procedure is to be preferred, as there is evidence that the risk of stroke or death is higher in asymptomatic patients who had CEA performed in combination with coronary artery bypass surgery (18.7\%) [87].

\section{Cerebral Hemodynamics and Metabolism}

The proposed mechanism of cerebral ischemia due to thrombo-embolic events from the atherosclerotic stenosis in the carotid artery is proven, but there is also supportive evidence that hemodynamic factors and the lack of collaterals can contribute to an ischemic event [50]. In addition, the recovery after a stroke depends on the ability of collateral pathways. The hemodynamic consequences of a CAS or occlusion depend on the collateral flow. If collateral flow is not adequate, reduction in cerebral blood flow $(\mathrm{CBF})$ or cerebral hypoperfusion can occur, which can produce low-flow neurological symptoms. The main collateral pathways are the contralateral common carotid artery and the vertebral arteries, but they can only serve as
Table 6. Diagnostics tools for investigating cerebral hemodynamics and metabolism

Transcranial doppler

TCD

Trans color-coded duplex ultrasonography

Computer angiography

Magnetic resonance imaging/angiography

Proton magnetic resonance spectroscopy

Single photon emission computer tomography

Positron emission tomography

TCCD

CTA

MRI/MRA

MRS

SPECT

PET

collaterals if there is a complete circle of Willis. Other collaterals are the ipsilateral ophthalmic artery and the leptomeningeal arteries. The circle of Willis seems to be the most important pathway between the extracranial arteries. Increased flow and vessel diameter of the circle of Willis have been demonstrated by MRA in patients with unilateral carotid occlusion [105]. This circle, however, shows a great variability. Anatomical, MRA and TCCD studies in neurological asymptomatic persons have shown, respectively, just $20-50,42$ and $50 \%$ complete circles [106108]. In people with cerebrovascular disease an incomplete circle of Willis is found in probably more than $50 \%$.

To improve selection of those patients with asymptomatic CAS who have an increased risk for stroke, investigations are focused on cerebral hemodynamics and metabolism.

In normal subjects with an intact cerebral autoregulation, both cerebral perfusion pressure (CPP) and cerebral blood flow (CBF) are maintained despite fluctuations in blood pressure (stage 0 ).

Reduced collateral flow causes diminished CPP and is accompanied by vasodilatation of cerebral vessels. This, in turn, leads to a decrease in the vascular resistance and an increase in CBF, which is associated with an increase of the cerebral blood volume (CBV). This is called cerebrovascular reactivity (CVR) or hemodynamic reserve capacity (stage 1). If CPP diminishes further, this compensatory vasodilatation mechanism is exhausted and CBF will decline (hypoperfusion). The only remaining mechanism to maintain normal cerebral metabolic rate of oxygen $\left(\mathrm{CMRO}_{2}\right)$ is to increase cerebral oxygen extraction fraction (COEF), which is called the oxygen reserve capacity (stage 2). A further drop in CPP will result in a decrease in $\mathrm{CMRO}_{2}$, which characterizes the stage of reversible or irreversible ischemia (stage 3 ).

Most other diagnostic modalities (table 6) for patient selection in asymptomatic CAS attempt to assess the 
above-mentioned (regional) cerebral hemodynamic and metabolic parameters and to relate these parameters with improvement in cerebral autoregulation after CEA or with risk of future neurological symptoms.

\section{TransCranial Doppler (TCD) and/or TransCranial} Color-Coded Duplex (TCCD)

CVR can be assessed using TCD and/or TCCD by measuring blood flow velocity in the middle cerebral artery, which is proportional to CBF. In the healthy brain, an increase in blood velocity will be measured after administration of vasodilatary agents (inhalation of 3-8\% $\mathrm{CO}_{2}$, acetazolamide) or by induction of hypercapnia using the breath-holding test. In the hemodynamically compromised brain with impaired cerebral autoregulation or exhausted CVR no increase of the blood velocity after vasodilatation occurs, because the vessels are already maximally vasodilated. There are data to suggest that reduced CVR ipsilateral to a carotid occlusion constitutes an increased risk of ipsilateral stroke compared with carotid occlusion with normal reactivity [109]. After CEA, diminished collateral flow is founded and CVR improves, not only on the side of surgery, but also on the side of contralateral carotid occlusion, suggesting an improved hemodynamic state [110-113].

Recent prospective data have confirmed that patients with impaired CVR and/or decreased number of collaterals or incomplete circle of Willis have an increased risk of neurological ischemic events. Markus et al. [114] found an odds ratio of 14.4 of ipsilateral stroke and TIA in patients with carotid occlusion and/or stenosis and exhausted reactivity. Vernieri et al. [115] found a significant risk of ipsilateral stroke in patients with impaired CVR on the side of a carotid occlusion and a decreased number of collaterals (32.7 vs. $0 \%$ ).

With TCCD, a relative new technique, the configuration of the circle of Willis and the flow direction and velocity of the intracranial vessels can be studied. A higher incidence of deficiency of anterior collateral flow and stroke was described [116].

The encouraging results of all these studies justify further investigations to clarify the value of TCD and/or TCCD in selecting patients with asymptomatic CAS who are at high risk for stroke.

\section{Magnetic Resonance Imaging (MRI)}

Morphology of the circle of Willis, flow patterns and size of vessels can be assessed by MRA [105]. Patients with an occluded internal carotid artery and an incomplete circle of Willis, as shown by MRA, have a signifi- cantly increased risk of ipsilateral stroke, compared with similar patients with a complete circle of Willis [117]. In asymptomatic patients, prevalence of anterior collateral flow and vessel diameter of the anterior communicating artery was increased, compared to symptomatic patients [118]. The role of MRA in selecting asymptomatic patients with CAS for CEA has still to be determined, but it was suggested that asymptomatic patient with CAS and adequate collateral compensation will probably not benefit from CEA [119].

Another option of MRI is that with the use of intravenous contrast, $\mathrm{CBV}$ and $\mathrm{CBF}$ can be measured. Increased $\mathrm{CBV}$ is indicative of compensatory vasodilatation according to stage 1 (hemodynamic reserve capacity). In perfusion-weighted MRI semiquantative values of CBV can be obtained and differences in cerebral hemodynamics in carotid artery stenoses $<$ and $>80 \%$ have been reported $[120,121]$. With dynamic susceptibility-contrastenhanced MRI and the use of an arterial input function, also absolute values of $\mathrm{CBF}$ and $\mathrm{CBV}$ can be obtained. Consistent values of CBF and CBV have been described in PET and MRI studies in patients with carotid artery disease [122]. There have been no reports yet investigating whether diminished cerebral hemodynamics calculated with MRI is associated with increased risk of stroke in asymptomatic CAS.

\section{Magnetic Resonance Spectroscopy (MRS)}

With MRS the concentrations of N-acetyl-aspartate (NAA), a marker of neuronal intregity, lactate, a marker of anaerobic metabolism, and choline, a molecule involved in cellular membranes and synthesis of acetylcholine in neurons, can be measured. It has been hypothesized that cerebral hypoperfusion or ischemia is accompanied with reduced concentrations of NAA and/or increased concentrations of lactate, while the interpretation of choline is more complicated. In symptomatic and asymptomatic patients changes of metabolite ratios and lactate has been reported before and after CEA [123-125]. Comments on these studies are variation in tissue sampling, large voxel sampling and absolute values of metabolites seems to be preferred above ratios, because ratios depend on two changing metabolites [126, 127]. Lythgoe et al. [127] studied absolute values of NAA and lactate in asymptomatic patients with CAS or carotid occlusion and an abnormal carbon dioxide reactivity. Normal values of NAA and no lactate was demonstrated. It was concluded that MRS, in spite of the reduced CVR as indicator for cerebral hypoperfusion, seems to be unlikely to help in the selection of patients with asymptomatic CAS for CEA. 


\section{Single Photon Emission Computer Tomography} (SPECT)

In SPECT radiopharmaceutical tracers, such as technetium-hexamethyl propyleneamine oxine (HMPAO), are used to determine regional $\mathrm{CBF}$. In combination with acetazolamide (ACZ) inducing cerebral vasodilatation, CVR can be assessed. Resting (without ACZ) and stress studies (with ACZ), comparable to the persantin-thallium scan in cardiology, are necessary to demonstrate changes in CBF and to detect areas of impaired hemodynamic reserve capacity. Studies in symptomatic as well as asymptomatic CAS have shown improvement of the hemodynamic reserve capacity in $50-80 \%$ of patients after CEA [128-131]. For selecting asymptomatic patients for CEA, SPECT seems not specific and sensitive compared to other diagnostic modalities.

\section{Positron Emission Tomography (PET)}

The only available diagnostic imaging modality which can quantify not only cerebral perfusion, but also cerebral metabolic rate of oxygen and especially the cerebral oxygen extraction fraction (OEF) in different regions of the brain is PET [132]. In patients with compromised cerebral perfusion increased OEF can be found. In these patients cerebral vascular reactivity is severely disturbed not only leading to maximal vasodilatation of the cerebral vessels but also to increased oxygen extraction from the blood. There is ample evidence to suggest that patients with increased OEF have a significantly increased risk to develop stroke, particularly patients with a carotid occlusion [133-136]. Improvement of cerebral hemodynamics according to PET has been described after extracranial-to-intracranial surgery and after CEA for symptomatic patients [137]. Most benefit will probably be achieved in patients with symptomatic carotid occlusion using extracranial-to-intracranial bypass [138]. If a carotid occlusion exists, restoration of cerebral hemodynamics can also be achieved by CEA of an asymptomatic contralateral CAS or by endarterectomy of an ipsilateral external carotid artery. In the presence of bilateral asymptomatic CAS and disturbed cerebral hemodynamics as determined by PET, prophylactic CEA seems justified, although the prevalence of this constellation is unknown and is likely to be very low.

Although presently the availability of PET is limited, its application in other disciplines of medicine (oncology, cardiology) warrants the expectation that PET will be introduced in general practice in the future and can have its merits in selecting patients with asymptomatic CAS and increased risk of stroke for CEA.

\section{Conclusion}

According to the results of ACAS and ACST, there is a small, but significant benefit of operating asymptomatic CAS $>60 \%$, but follow-up studies and prospective data have shown that, in general, the natural history of asymptomatic CAS is mild, that surgical results are not always comparable and that more information is needed to identify high risk patients for cerebrovascular events. Nowadays, a more selective approach is noticed, operating only patients aged $<75$ years with asymptomatic CAS $>80 \%$ stenosis or patients with carotid pathology on both sides and an abnormal CVR. More convincing evidence is needed to determine whether certain patients with reduced CVR are prone to cerebrovascular events. Studies must be concentrated on plaque characteristics and instability, cerebral hemodynamics and metabolism to improve patient selection. The limitation of TCD, TCCD, MRI and SPECT is that they can only give information on CVR and the hemodynamic reserve capacity (stage 1), while PET also can determine the oxygen reserve capacity (stage 2). In theory, only PET can identify patients with the highest degree of hemodynamic compromise and the highest risk for neurological symptoms caused by chronic cerebral hypoperfusion.

It is hypothesized that in the future three groups of patients with asymptomatic CAS will benefit from CEA or a revascularization procedure. The first group consist of patients with plaque instability identified with MRA and/or duplex, with or without silent embolic signals, the second of patients with insufficient collateral circulation detected by TCD, TCCD and/or MRA, and the third of patients with severe metabolic compromise, characterized by increased OEF as measured with PET. 


\section{References}

1 Randomised Trial of Endarterectomy for Recently Symptomatic Carotid Stenosis: Final results of the MRC European Carotid Surgery Trial (ECST). Lancet 1998;351:13791387.

-2 Beneficial Effect of Carotid Endarterectomy in Symptomatic Patients with High-Grade Carotid Stenosis: North American Symptomatic Carotid Endarterectomy Trial Collaborators. N Engl J Med 1991;325:445-453.

-3 Endarterectomy for Asymptomatic Carotid Artery Stenosis: Executive Committee for the Asymptomatic Carotid Atherosclerosis Study. JAMA 1995;273:1421-1428.

$\checkmark 4$ Halliday A, Mansfield A, Marro J, Peto C, Peto R, Potter J, Thomas D: Prevention of disabling and fatal strokes by successful carotid endarterectomy in patients without recent neurological symptoms: randomised controlled trial. Lancet 2004;363:14911502.

5 Benavente O, Moher D, Pham B: Carotid endarterectomy for asymptomatic carotid stenosis: a meta-analysis. BMJ 1998;317: 1477-1480.

6 Moore WS, Young B, Baker WH, Robertson JT, Toole JF, Vescera CL, Howard VJ: Surgical results: a justification of the surgeon selection process for the ACAS trial. The ACAS Investigators. J Vasc Surg 1996;23:323-328.

7 Naylor AR: Does the modern concept of 'best medical therapy' render carotid surgery obsolete? Eur J Vasc Endovasc Surg 2004;28: 457-461.

8 Inzitari D, Eliasziw M, Gates P, Sharpe BL, Chan RK, Meldrum HE, Barnett HJ: The causes and risk of stroke in patients with asymptomatic internal-carotid-artery stenosis. North American Symptomatic Carotid Endarterectomy Trial Collaborators. N Engl J Med 2000;342:1693-1700.

$\checkmark 9$ Hill AB: Should patients be screened for asymptomatic carotid artery stenosis? Can J Surg 1998;41:208-213.

-10 Hennerici M, Aulich A, Sandmann W, Freund HJ: Incidence of asymptomatic extracranial arterial disease. Stroke 1981;12: 750-758.

-11 Ramsey DE, Miles RD, Lambeth A, Sumner DS: Prevalence of extracranial carotid artery disease: a survey of an asymptomatic population with noninvasive techniques. J Vasc Surg 1987;5:584-588.

$\checkmark 12$ Hennerici M, Hulsbomer HB, Hefter $\mathrm{H}$, Lammerts D, Rautenberg W: Natural history of asymptomatic extracranial arterial disease: results of a long-term prospective study. Brain 1987; 110:777-791.

$\checkmark 13$ Josse MO, Touboul PJ, Mas JL, Laplane D, Bousser MG: Prevalence of asymptomatic internal carotid artery stenosis. Neuroepidemiology 1987;6:150-152.
14 Colgan MP, Strode GR, Sommer JD, Gibbs JL, Sumner DS: Prevalence of asymptomatic carotid disease: results of duplex scanning in 348 unselected volunteers. J Vasc Surg 1988; 8:674-678

15 Faggioli GL, Curl GR, Ricotta JJ: The role of carotid screening before coronary artery bypass. J Vasc Surg 1990;12:724-729.

16 Ahn SS, Baker JD, Walden K, Moore WS: Which asymptomatic patients should undergo routine screening carotid duplex scan? Am J Surg 1991;162:180-183.

17 Klop RB, Eikelboom BC, Taks AC: Screening of the internal carotid arteries in patients with peripheral vascular disease by colourflow duplex scanning. Eur J Vasc Surg 1991; 5:41-45.

18 Ellis MR, Franks PJ, Cuming R, Powell JT, Greenhalgh RM: Prevalence, progression and natural history of asymptomatic carotid stenosis: is there a place for carotid endarterectomy? Eur J Vasc Surg 1992;6:172-177.

19 O'Leary DH, Polak JF, Kronmal RA, Kittner SJ, Bond MG, Wolfson SK Jr, Bommer W, Price TR, Gardin JM, Savage PJ: Distribution and correlates of sonographically detected carotid artery disease in the Cardiovascular Health Study. The CHS Collaborative Research Group. Stroke 1992;23:1752-1760.

20 Fine-Edelstein JS, Wolf PA, O'Leary DH, Poehlman $\mathrm{H}$, Belanger AJ, Kase CS, D'Agostino RB: Precursors of extracranial carotid atherosclerosis in the Framingham Study. Neurology 1994;44:1046-1050.

21 Gentile AT, Taylor LM Jr, Moneta GL, Porter JM: Prevalence of asymptomatic carotid stenosis in patients undergoing infrainguinal bypass surgery. Arch Surg 1995;130:900904.

22 Marek J, Mills JL, Harvich J, Cui H, Fujitani RM: Utility of routine carotid duplex screening in patients who have claudication. J Vasc Surg 1996;24:572-577.

23 House AK, Bell R, House J, Mastaglia F, Kumar A, D'Antuono M: Asymptomatic carotid artery stenosis associated with peripheral vascular disease: a prospective study. Cardiovasc Surg 1999;7:44-49.

24 Ascher E, DePippo P, Salles-Cunha S, Marchese J, Yorkovich W: Carotid screening with duplex ultrasound in elderly asymptomatic patients referred to a vascular surgeon: is it worthwhile? Ann Vasc Surg 1999; 13:164-168

25 Simons PC, Algra A, Eikelboom BC, Grobbee DE, van der Graaf Y: Carotid artery stenosis in patients with peripheral arterial disease: the SMART study. SMART study group. J Vasc Surg 1999;30:519-525.

26 Cheng SW, Wu LL, Lau H, Ting AC, Wong J: Prevalence of significant carotid stenosis in Chinese patients with peripheral and coronary artery disease. Aust NZ J Surg 1999;69: 44-47.
27 Qureshi AI, Janardhan V, Bennett SE, Luft AR, Hopkins LN, Guterman LR: Who should be screened for asymptomatic carotid artery stenosis? Experience from the Western New York Stroke Screening Program. J Neuroimaging 2001;11:105-111.

28 Cina CS, Safar HA, Maggisano R, Bailey R, Clase CM: Prevalence and progression of internal carotid artery stenosis in patients with peripheral arterial occlusive disease. J Vasc Surg 2002;36:75-82.

-29 Chambers BR, Norris JW: Outcome in patients with asymptomatic neck bruits. N Engl J Med 1986;315:860-865.

-30 Autret A, Pourcelot L, Saudeau D, Marchal C, Bertrand P, de Boisvilliers S: Stroke risk in patients with carotid stenosis. Lancet 1987; i:888-890.

31 O'Holleran LW, Kennelly MM, McClurken M, Johnson JM: Natural history of asymptomatic carotid plaque: five year follow-up study. Am J Surg 1987;154:659-662.

32 Norris JW, Zhu CZ, Bornstein NM, Chambers BR: Vascular risks of asymptomatic carotid stenosis. Stroke 1991;22:1485-1490.

33 Mess W, Steinke W, Rautenberg W, Hennerici $\mathrm{M}$ : Asymptomatic extracranial arterial disease. Cerebrovasc Dis 1992;2:199.

34 Shanik GD, Moore DJ, Leahy A, Grouden MC, Colgan MP: Asymptomatic carotid stenosis: a benign lesion? Eur J Vasc Surg 1992; 6:10-15.

35 Bock RW, Gray-Weale AC, Mock PA, App SM, Robinson DA, Irwig L, Lusby RJ: The natural history of asymptomatic carotid artery disease. J Vasc Surg 1993;17:160-169.

-36 Hobson RW, Weiss DG, Fields WS, Goldstone J, Moore WS, Towne JB, Wright CB: Efficacy of carotid endarterectomy for asymptomatic carotid stenosis. The Veterans Affairs Cooperative Study Group. N Engl J Med 1993;328:221-227.

37 Risk of Stroke in the Distribution of an Asymptomatic Carotid Artery: The European Carotid Surgery Trialists Collaborative Group. Lancet 1995;345:209-212.

-38 Naylor AR, John T, Howlett J, Gillespie I, Allan P, Ruckley CV: Fate of the non-operated carotid artery after contralateral endarterectomy. Br J Surg 1995;82:44-48.

39 Tong Y, Royle J: Outcome of patients with symptomless carotid bruits: a prospective study. Cardiovasc Surg 1996;4:174-180.

-40 Mackey AE, Abrahamowicz M, Langlois Y, Battista R, Simard D, Bourque F, Leclerc J, Cote R: Outcome of asymptomatic patients with carotid disease. Asymptomatic Cervical Bruit Study Group. Neurology 1997;48: 896-903.

41 Irvine CD, Cole SE, Foley PX, Brookes ST, Morgan M, Wilson Y, Hayward J, Baird RN, Lamont PM: Unilateral asymptomatic carotid disease does not require surgery. Eur J Vasc Endovasc Surg 1998;16:245-253. 
42 Longstreth WT Jr, Shemanski L, Lefkowitz D, O’Leary DH, Polak JF, Wolfson SK Jr: Asymptomatic internal carotid artery stenosis defined by ultrasound and the risk of subsequent stroke in the elderly. The Cardiovascular Health Study. Stroke 1998;29: 2371-2376.

43 Nadareishvili ZG, Rothwell PM, Beletsky V, Pagniello A, Norris JW: Long-term risk of stroke and other vascular events in patients with asymptomatic carotid artery stenosis. Arch Neurol 2002;59:1162-1166.

44 Nicolaides AN, Kakkos SK, Griffin M, Sabetai M, Dhanjil S, Tegos T, Thomas DJ, Giannoukas A, Geroulakos G, Georgiou N, Francis S, Ioannidou E, Dore CJ: Severity of asymptomatic carotid stenosis and risk of ipsilateral hemispheric ischaemic events: results from the ACSRS study. Eur J Vasc Endovasc Surg 2005;30:275-284.

45 Obuchowski NA, Modic MT, Magdinec M, Masaryk TJ: Assessment of the efficacy of noninvasive screening for patients with asymptomatic neck bruits. Stroke 1997;28: 1330-1339.

$\checkmark 46$ Clase CM, Cina CS: Medical management versus investigate-and-operate strategy in asymptomatic carotid stenosis: a decision analysis. J Vasc Surg 2002;36:541-548.

-47 Klop RB, Taks AC, Welten RJ, Eikelboom BC: Outcome of progression from carotid stenosis to occlusion. Eur J Vasc Surg 1992;6: 263-268.

-48 Cote R, Barnett HJ, Taylor DW: Internal carotid occlusion: a prospective study. Stroke 1983;14:898-902.

$\checkmark 49$ Nicholls SC, Kohler TR, Bergelin RO, Primozich JF, Lawrence RL, Strandness DE Jr: Carotid artery occlusion: natural history. J Vasc Surg 1986;4:479-485.

50 Klijn CJ, Kappelle LJ, Tulleken CA, van Gijn $\mathrm{J}$ : Symptomatic carotid artery occlusion. A reappraisal of hemodynamic factors. Stroke 1997;28:2084-2093.

-51 Rockman CB, Riles TS, Lamparello PJ, Giangola G, Adelman MA, Stone D, Guareschi C, Goldstein J, Landis R: Natural history and management of the asymptomatic, moderately stenotic internal carotid artery. J Vasc Surg 1997;25:423-431.

-52 Long A, Lepoutre A, Corbillon E, Branchereau A: Critical review of non- or minimally invasive methods (duplex ultrasonography, MR- and CT-angiography) for evaluating stenosis of the proximal internal carotid artery. Eur J Vasc Endovasc Surg 2002;24:4352.

-53 Nederkoorn PJ, Mali WP, Eikelboom BC, Elgersma OE, Buskens E, Hunink MG, Kappelle LJ, Buijs PC, Wust AF, van der Lugt A, van der Graaf Y: Preoperative diagnosis of carotid artery stenosis: accuracy of noninvasive testing. Stroke 2002;33:2003-2008.

54 Hatsukami TS, Healy DA, Primozich JF, Bergelin RO, Strandness DE Jr: Fate of the carotid artery contralateral to endarterectomy. J Vasc Surg 1990;11:244-250.
55 Johnson BF, Verlato F, Bergelin RO, Primozich JF, Strandness E Jr: Clinical outcome in patients with mild and moderate carotid artery stenosis. J Vasc Surg 1995;21:120126.

56 Liapis C, Kakisis J, Papavassiliou V, Ntanou A, Kontopoulou S, Kaperonis E, Koumakis K, Gogas J: Internal carotid artery stenosis: rate of progression. Eur J Vasc Endovasc Surg 2000;19:111-117.

57 Mansour MA, Littooy FN, Watson WC, Blumofe KA, Heilizer TJ, Steffen GF, Chmura C, Kang SS, Labropoulos N, Greisler HP, Fisher SG, Baker WH: Outcome of moderate carotid artery stenosis in patients who are asymptomatic. J Vasc Surg 1999;29:217-225.

58 Muluk SC, Muluk VS, Sugimoto H, Rhee RY, Trachtenberg J, Steed DL, Jarrett F, Webster MW, Makaroun MS: Progression of asymptomatic carotid stenosis: a natural history study in 1,004 patients. J Vasc Surg 1999;29: 208-214.

59 Olin JW, Fonseca C, Childs MB, Piedmonte MR, Hertzer NR, Young JR: The natural history of asymptomatic moderate internal carotid artery stenosis by duplex ultrasound. Vasc Med 1998;3:101-108.

60 Roederer GO, Langlois YE, Lusiani L, Jager KA, Primozich JF, Lawrence RJ, Phillips DJ, Strandness DE Jr: Natural history of carotid artery disease on the side contralateral to endarterectomy. J Vasc Surg 1984;1:62-72.

61 Golledge J, Greenhalgh RM, Davies AH: The symptomatic carotid plaque. Stroke 2000;31: 774-781.

62 Gray-Weale AC, Graham JC, Burnett JR, Byrne K, Lusby RJ: Carotid artery atheroma: comparison of preoperative B-mode ultrasound appearance with carotid endarterectomy specimen pathology. J Cardiovasc Surg (Torino) 1988;29:676-681.

63 Geroulakos G, Ramaswami G, Nicolaides A James K, Labropoulos N, Belcaro G, Holloway $\mathrm{M}$ : Characterization of symptomatic and asymptomatic carotid plaques using high-resolution real-time ultrasonography. Br J Surg 1993;80:1274-1277.

64 Tegos TJ, Stavropoulos P, Sabetai MM, Khodabakhsh P, Sassano A, Nicolaides AN: Determinants of carotid plaque instability: echoicity versus heterogeneity. Eur J Vasc Endovasc Surg 2001;22:22-30.

65 Grogan JK, Shaalan WE, Cheng H, Gewertz B, Desai T, Schwarze G, Glagov S, Lozanski L, Griffin A, Castilla M, Bassiouny HS: Bmode ultrasonographic characterization of carotid atherosclerotic plaques in symptomatic and asymptomatic patients. J Vasc Surg 2005;42:435-441.

66 Geroulakos G, Domjan J, Nicolaides A, Stevens J, Labropoulos N, Ramaswami G, Belcaro G, Mansfield A: Ultrasonic carotid artery plaque structure and the risk of cerebral infarction on computed tomography. J Vasc Surg 1994;20:263-266.
67 Sabetai MM, Tegos TJ, Clifford C, Dhanjil S, Belcaro G, Kakkos S, Kalodiki E, Stevens JM, Nicolaides AN: Carotid plaque echogenicity and types of silent CT-brain infarcts. Is there an association in patients with asymptomatic carotid stenosis? Int Angiol 2001;20:5157.

68 Gronholdt ML, Nordestgaard BG, Schroeder TV, Vorstrup S, Sillesen H: Ultrasonic echolucent carotid plaques predict future strokes. Circulation 2001;104:68-73.

69 AbuRahma AF, Wulu JT Jr, Crotty B: Carotid plaque ultrasonic heterogeneity and severity of stenosis. Stroke 2002;33:1772-1775.

770 Langsfeld M, Gray-Weale AC, Lusby RJ: The role of plaque morphology and diameter reduction in the development of new symptoms in asymptomatic carotid arteries. J Vasc Surg 1989;9:548-557.

71 Gronholdt ML: B-mode ultrasound and spiral CT for the assessment of carotid atherosclerosis. Neuroimaging Clin N Am 2002;12: 421-435.

72 Georgiadis D, Grosset DG, Quin RO, Nichol JA, Bone I, Lees KR: Detection of intracranial emboli in patients with carotid disease. Eur J Vasc Surg 1994;8:309-314.

73 Siebler M, Nachtmann A, Sitzer M, Rose G, Kleinschmidt A, Rademacher J, Steinmetz $\mathrm{H}$ : Cerebral microembolism and the risk of ischemia in asymptomatic high-grade internal carotid artery stenosis. Stroke 1995;26: 2184-2186.

74 Orlandi G, Parenti G, Bertolucci A, Murri L: Silent cerebral microembolism in asymptomatic and symptomatic carotid artery stenoses of low and high degree. Eur Neurol 1997;38:39-43.

75 Van Zuilen EV, van Gijn J, Ackerstaff RG: The clinical relevance of cerebral microemboli detection by transcranial Doppler ultrasound. J Neuroimaging 1998;8:32-37.

76 Molloy J, Markus HS: Asymptomatic embolization predicts stroke and TIA risk in patients with carotid artery stenosis. Stroke 1999;30:1440-1443.

$>77$ Shaalan WE, Cheng H, Gewertz B, McKinsey JF, Schwartz LB, Katz D, Cao D, Desai T, Glagov S, Bassiouny HS: Degree of carotid plaque calcification in relation to symptomatic outcome and plaque inflammation. J Vasc Surg 2004;40:262-269.

78 Yuan C, Miller ZE, Cai J, Hatsukami T: Carotid atherosclerotic wall imaging by MRI. Neuroimaging Clin N Am 2002;12:391-401, vi.

79 Cappeller WA, Schluter A, Hammer A, Jassoy A: Morphologic carotid plaque characteristics in symptomatic and asymptomatic patients on MRI compared to histopathologic and macroscopic criteria. Chirurg 2003; 74:743-748 
-80 Murphy RE, Moody AR, Morgan PS, Martel AL, Delay GS, Allder S, MacSweeney ST, Tennant WG, Gladman J, Lowe J, Hunt BJ: Prevalence of complicated carotid atheroma as detected by magnetic resonance direct thrombus imaging in patients with suspected carotid artery stenosis and previous acute cerebral ischemia. Circulation 2003;107: 3053-3058.

81 Robless P, Baxter A, Byrd S, Emson M, Halliday A: The prevalence of cerebral infarcts in the Asymptomatic Carotid Surgery Trial (ACST) in relation to prior contralateral symptoms. Int Angiol 1998;17:187-193.

-82 Hougaku H, Matsumoto M, Handa N, Maeda $\mathrm{H}$, Itoh $\mathrm{T}$, Tsukamoto $\mathrm{Y}$, Kamada $\mathrm{T}$ : Asymptomatic carotid lesions and silent cerebral infarction. Stroke 1994;25:566-570.

83 Cao P, Zannetti S, Giordano G, De Rango P, Parlani G, Caputo N: Cerebral tomographic findings in patients undergoing carotid endarterectomy for asymptomatic carotid stenosis: short-term and long-term implications. J Vasc Surg 1999;29:995-1005.

84 Brott T, Tomsick T, Feinberg W, Johnson C, Biller J, Broderick J, Kelly M, Frey J, Schwartz S, Blum C: Baseline silent cerebral infarction in the asymptomatic carotid atherosclerosis study. Stroke 1994;25:1122-1129.

85 Baker WH, Howard VJ, Howard G, Toole JF: Effect of contralateral occlusion on long-term efficacy of endarterectomy in the asymptomatic carotid atherosclerosis study (ACAS). ACAS Investigators. Stroke 2000; 31:2330-2334.

86 AbuRahma AF, Metz MJ, Robinson PA: Natural history of $>$ or $=60 \%$ asymptomatic carotid stenosis in patients with contralateral carotid occlusion. Ann Surg 2003;238:551561.

87 Goldstein LB, Samsa GP, Matchar DB, Oddone EZ: Multicenter review of preoperative risk factors for endarterectomy for asymptomatic carotid artery stenosis. Stroke 1998; 29:750-753.

88 Rothwell PM, Slattery J, Warlow CP: Clinical and angiographic predictors of stroke and death from carotid endarterectomy: systematic review. BMJ 1997;315:1571-1577.

-89 Klijn CJ, van Buren PA, Kappelle LJ, Tulleken CA, Eikelboom BC, Algra A, van Gijn J: Outcome in patients with symptomatic occlusion of the internal carotid artery. Eur J Vasc Endovasc Surg 2000;19:579-586.

-90 Reed AB, Gaccione P, Belkin M, Donaldson MC, Mannick JA, Whittemore AD, Conte MS: Preoperative risk factors for carotid endarterectomy: defining the patient at high risk. J Vasc Surg 2003;37:1191-1199.

-91 Pulli R, Dorigo W, Barbanti E, Azas L, Russo D, Matticari S, Chiti E, Pratesi C: Carotid endarterectomy with contralateral carotid artery occlusion: is this a higher risk subgroup? Eur J Vasc Endovasc Surg 2002;24: 63-68.
\$2 Rockman CB, Su W, Lamparello PJ, Adelman MA, Jacobowitz GR, Gagne PJ, Landis $\mathrm{R}$, Riles TS: A reassessment of carotid endarterectomy in the face of contralateral carotid occlusion: surgical results in symptomatic and asymptomatic patients. J Vasc Surg 2002;36:668-673.

$\$ 93$ AbuRahma AF, Robinson P, Holt SM, Herzog TA, Mowery NT: Perioperative and late stroke rates of carotid endarterectomy contralateral to carotid artery occlusion: results from a randomized trial. Stroke 2000; 31:1566-1571.

94 Julia P, Chemla E, Mercier F, Renaudin JM, Fabiani JN: Influence of the status of the contralateral carotid artery on the outcome of carotid surgery. Ann Vasc Surg 1998;12: 566-571.

95 Bond R, Narayan SK, Rothwell PM, Warlow CP: Clinical and radiographic risk factors for operative stroke and death in the European carotid surgery trial. Eur J Vasc Endovasc Surg 2002;23:108-116.

-96 Akbari CM, Pulling MC, Pomposelli FB Jr Gibbons GW, Campbell DR, LoGerfo FW: Gender and carotid endarterectomy: does it matter? J Vasc Surg 2000;31:1103-1108.

97 Rockman CB, Castillo J, Adelman MA, Jacobowitz GR, Gagne PJ, Lamparello PJ, Landis R, Riles TS: Carotid endarterectomy in female patients: are the concerns of the Asymptomatic Carotid Atherosclerosis Study valid? J Vasc Surg 2001;33:236-240.

-98 Perler BA, Dardik A, Burleyson GP, Gordon TA, Williams GM: Influence of age and hospital volume on the results of carotid endarterectomy: a statewide analysis of 9,918 cases. J Vasc Surg 1998;27:25-31.

-99 Kerdiles Y, Lucas A, Podeur L, Ferte P, Cardon A: Results of carotid surgery in elderly patients. J Cardiovasc Surg (Torino) 1997; 38:327-334.

100 O'Hara PJ, Hertzer NR, Mascha EJ, Beven EG, Krajewski LP, Sullivan TM: Carotid endarterectomy in octogenarians: early results and late outcome. J Vasc Surg 1998;27: 860-869.

101 Joakimsen O, Bonaa KH, Mathiesen EB, Stensland-Bugge E, Arnesen E: Prediction of mortality by ultrasound screening of a general population for carotid stenosis: the Tromso Study. Stroke 2000;31:1871-1876.

102 Paciaroni M, Caso V, Acciarresi M, Baumgartner RW, Agnelli G: Management of asymptomatic carotid stenosis in patients undergoing general and vascular surgical procedures. J Neurol Neurosurg Psychiatry 2005;76:1332-1336.

103 Naylor AR, Mehta Z, Rothwell PM, Bell PR: Carotid artery disease and stroke during coronary artery bypass: a critical review of the literature. Eur J Vasc Endovasc Surg 2002;23:283-294.
104 Schwartz LB, Bridgman AH, Kieffer RW, Wilcox RA, McCann RL, Tawil MP, Scott SM: Asymptomatic carotid artery stenosis and stroke in patients undergoing cardiopulmonary bypass. J Vasc Surg 1995;21: 146-153.

105 Hartkamp MJ, van der Grond J, van Everdingen KJ, Hillen B, Mali WP: Circle of Willis collateral flow investigated by magnetic resonance angiography. Stroke 1999; 30:2671-2678.

106 Alpers BJ, Berry RG, Paddison RM: Anatomical studies of the circle of Willis in normal brain. AMA Arch Neurol Psychiatry 1959;81:409-418.

107 Krabbe-Hartkamp MJ, van der Grond J, de Leeuw FE, de Groot JC, Algra A, Hillen B, Breteler MM, Mali WP: Circle of Willis: morphologic variation on three-dimensional time-of-flight MR angiograms. Radiology 1998;207:103-111.

108 Hoksbergen AW, Fulesdi B, Legemate DA, Csiba L: Collateral configuration of the circle of Willis: transcranial color-coded duplex ultrasonography and comparison with postmortem anatomy. Stroke 2000;31: 1346-1351.

109 Kleiser B, Widder B: Course of carotid artery occlusions with impaired cerebrovascular reactivity. Stroke 1992;23:171-174.

110 Markus HS, Harrison MJ, Adiseshiah M: Carotid endarterectomy improves haemodynamics on the contralateral side: implications for operating contralateral to an occluded carotid artery. Br J Surg 1993;80: 170-172.

111 Visser GH, van Huffelen AC, Wieneke GH, Eikelboom BC: Bilateral increase in $\mathrm{CO} 2$ reactivity after unilateral carotid endarterectomy. Stroke 1997;28:899-905.

112 Vriens EM, Wieneke GH, Hillen B, Eikelboom BC, van Huffelen AC, Visser GH: Flow redistribution in the major cerebral arteries after carotid endarterectomy: a study with transcranial Doppler scan. J Vasc Surg 2001;33:139-147.

113 White RP, Markus HS: Impaired dynamic cerebral autoregulation in carotid artery stenosis. Stroke 1997;28:1340-1344.

114 Markus H, Cullinane M: Severely impaired cerebrovascular reactivity predicts stroke and TIA risk in patients with carotid artery stenosis and occlusion. Brain 2001;124: 457-467.

115 Vernieri F, Pasqualetti P, Matteis M, Passarelli F, Troisi E, Rossini PM, Caltagirone C, Silvestrini M: Effect of collateral blood flow and cerebral vasomotor reactivity on the outcome of carotid artery occlusion. Stroke 2001;32:1552-1558.

116 Hoksbergen AW, Legemate DA, Csiba L, Csati G, Siro P, Fulesdi B: Absent collateral function of the circle of Willis as risk factor for ischemic stroke. Cerebrovasc Dis 2003; 16:191-198. 
-117 Schomer DF, Marks MP, Steinberg GK, Johnstone IM, Boothroyd DB, Ross MR, Pelc NJ, Enzmann DR: The anatomy of the posterior communicating artery as a risk factor for ischemic cerebral infarction. $\mathrm{N}$ Engl J Med 1994;330:1565-1570.

$\checkmark 118$ Hendrikse J, Eikelboom BC, van der Grond $\mathrm{J}$ : Magnetic resonance angiography of collateral compensation in asymptomatic and symptomatic internal carotid artery stenosis. J Vasc Surg 2002;36:799-805.

$\checkmark 119$ Barnett HJ, Meldrum HE: Endarterectomy for carotid stenosis: new approaches in patient selection. Cerebrovasc Dis 2001; 11(suppl 1):105-111.

120 Schreiber WG, Guckel F, Stritzke P, Schmiedek P, Schwartz A, Brix G: Cerebral blood flow and cerebrovascular reserve capacity: estimation by dynamic magnetic resonance imaging. J Cereb Blood Flow Metab 1998; 18:1143-1156.

-121 Doerfler A, Eckstein HH, Eichbaum M, Heiland S, Benner T, Allenberg JR, Forsting M: Perfusion-weighted magnetic resonance imaging in patients with carotid artery disease before and after carotid endarterectomy. J Vasc Surg 2001;34:587-593.

122 Ostergaard L, Johannsen P, Host-Poulsen P, Vestergaard-Poulsen P, Asboe H, Gee AD, Hansen SB, Cold GE, Gjedde A, Gyldensted C: Cerebral blood flow measurements by magnetic resonance imaging bolus tracking: comparison with $[(15) \mathrm{O}] \mathrm{H}_{2} \mathrm{O}$ positron emission tomography in humans. J Cereb Blood Flow Metab 1998;18:935-940.

-123 van der Grond J, Balm R, Klijn CJ, Kapelle LJ, Eikelboom BC, Mali WP: Cerebral metabolism of patients with stenosis of the internal carotid artery before and after endarterectomy. J Cereb Blood Flow Metab 1996;16:320-326.
124 Visser GH, van der Grond J, van Huffelen AC, Wieneke GH, Eikelboom BC: Decreased transcranial Doppler carbon dioxide reactivity is associated with disordered cerebral metabolism in patients with internal carotid artery stenosis. J Vasc Surg 1999;30:252-260.

125 Kim GE, Lee JH, Cho YP: Can carotid endarterectomy improve metabolic status in patients with asymptomatic internal carotid artery flow lesion? Studies with localized in vivo proton magnetic resonance spectroscopy. J Vasc Surg 2002;36:559-564.

126 Lynch TG, Pipinos II, Boska MD: Regarding 'Can carotid endarterectomy improve metabolic status in patients with asymptomatic internal carotid artery flow lesion? Studies with localized in vivo proton magnetic resonance spectroscopy'. J Vasc Surg 2002;36:646-648.

127 Lythgoe D, Simmons A, Pereira A, Cullinane M, Williams S, Markus HS: Magnetic resonance markers of ischaemia: their correlation with vasodilatory reserve in patients with carotid artery stenosis and occlusion. J Neurol Neurosurg Psychiatry 2001;71:58-62.

128 Cikrit DF, Dalsing MC, Harting PS, Burt RW, Lalka SG, Sawchuk AP, Solooki B: Cerebral vascular reactivity assessed with acetazolamide single photon emission computer tomography scans before and after carotid endarterectomy. Am J Surg 1997; 174:193-197.

129 Cikrit DF, Dalsing MC, Lalka SG, Burt RW, Sawchuk AP, Solooki BA: The value of acetazolamide single photon emission computed tomography scans in the preoperative evaluation of asymptomatic critical carotid stenosis. J Vasc Surg 1999;30:599-605.

$>130$ Hosoda K, Fujita S, Kawaguchi T, Shose Y, Shibata Y, Tamaki N: Influence of degree of carotid artery stenosis and collateral pathways and effect of carotid endarterectomy on cerebral vasoreactivity. Neurosurgery 1998;42:988-994.
131 Tawes RL, Lull R: Value of single photon emission computerized imaging in the treatment of patients undergoing carotid endarterectomy. J Vasc Surg 1996;24:219225.

132 Baron JC: Clinical use of positron emission tomography in cerebrovascular diseases. Neurosurg Clin N Am 1996;7:653-664.

133 Yamauchi H, Fukuyama H, Nagahama Y, Nabatame H, Nakamura K, Yamamoto Y, Yonekura Y, Konishi J, Kimura J: Evidence of misery perfusion and risk for recurrent stroke in major cerebral arterial occlusive diseases from PET. J Neurol Neurosurg Psychiatry 1996;61:18-25.

134 Derdeyn CP, Yundt KD, Videen TO, Carpenter DA, Grubb RL Jr, Powers WJ: Increased oxygen extraction fraction is associated with prior ischemic events in patients with carotid occlusion. Stroke 1998;29: 754-758.

135 Grubb RL Jr, Derdeyn CP, Fritsch SM, Carpenter DA, Yundt KD, Videen TO, Spitznagel EL, Powers WJ: Importance of hemodynamic factors in the prognosis of symptomatic carotid occlusion. JAMA 1998;280: 1055-1060.

136 Yamauchi H, Fukuyama H, Nagahama Y, Nabatame H, Ueno M, Nishizawa S, Konishi J, Shio H: Significance of increased oxygen extraction fraction in five-year prognosis of major cerebral arterial occlusive diseases. J Nucl Med 1999;40:1992-1998.

137 Kuwabara Y, Ichiya Y, Sasaki M, Yoshida T, Fukumura T, Masuda K, Fujii K, Fukui M: PET evaluation of cerebral hemodynamics in occlusive cerebrovascular disease preand postsurgery. J Nucl Med 1998;39:760765.

-138 Derdeyn CP, Gage BF, Grubb RL Jr, Powers WJ: Cost-effectiveness analysis of therapy for symptomatic carotid occlusion: PET screening before selective extracranial-tointracranial bypass versus medical treatment. J Nucl Med 2000;41:800-807. 